Background Paper

Wealth Tax Commission

Valuation and

liquidity issues

for private

businesses:

quantitative

evidence

\title{
Author
}

Hannah Tarrant

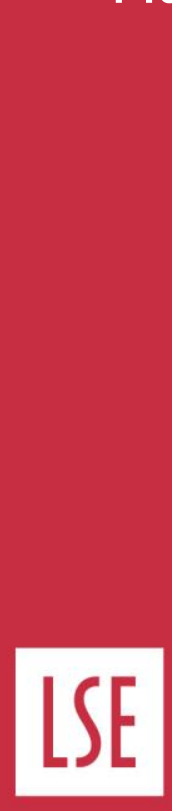

OF ECONOMICS AND
POLITICAL SCIENCE



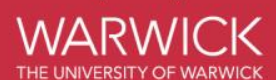




\section{VALUATION AND LIQUIDITY ISSUES FOR PRIVATE BUSINESSES: QUANTITATIVE EVIDENCE}

Hannah Tarrant, London School of Economics III

Wealth Tax Commission Background Paper no. 125

Published by the Wealth Tax Commission

www.ukwealth.tax 


\section{Acknowledgements}

The author thanks Arun Advani, Emma Chamberlain, and Andy Summers for helpful comments.

The Wealth Tax Commission acknowledges funding from the Economic and Social Research Council (ESRC) through the CAGE at Warwick (ES/L011719/1) and a COVID-19 Rapid Response Grant (ES/V012657/1), and a grant from Atlantic Fellows for Social and Economic Equity's COVID-19 Rapid Response Fund. 


\section{Abstract}

Taxing wealth held in private businesses poses two key challenges. First, they must be valued. This is not always straightforward particularly for businesses without an observable and consistent profit stream, and businesses with many intangible assets. Second, not all businesses generate sufficient income to fund wealth tax payments. This paper provides quantitative evidence on the empirical magnitude of these problems, documenting how many and which businesses could be challenging to value, and which business owners could face liquidity constraints. I then zoom in on farm businesses, a particular source of concern for some who worry that farming incomes are low relative to the value of land. I find that a minority of private businesses will be hard to value, and some businesses (including some farms) will face liquidity constraints. However, these problems are not widescale enough to be insurmountable. 


\section{Introduction}

A wealth tax which includes private businesses in the tax base would present two key challenges. First, businesses would need to be valued. This is not always straightforward, as not all businesses have a readily observable market value. Solutions to valuing businesses are discussed at length in Daly and Loutzenhiser (2020) and Ryan (2020). However, the applicability of different valuation approaches depends on factors such as whether a business has an observable and consistent profit stream, and how much of their value is held in intangible, hardto-value assets. Second, there is a concern that not all businesses generate sufficient income to pay the tax, rendering business owners liquidity constrained. This is a popular concern with regards to farming businesses in particular. Ultimately, the extent of these issues depends on how many businesses - particularly hard-to-value businesses- would be liable to pay under the chosen tax structure, the income they generate, and who owns them.

In this paper, I present quantitative evidence on the magnitude of these challenges based on what we can observe of the private business population in the UK. ${ }^{1}$ The paper is designed to complement the discussions of legal and administrative issues explored in Daly and Loutzenhiser (2020) and Loutzenhiser and Mann (2020). I explore the evidence on valuation and liquidity issues among the business population as a whole (Sections 3 and 4), before turning specifically to farming businesses (Section 5).

It is difficult to reach a conclusion on the number of businesses that would need to be valued under a wealth tax, as there is little information available on the value of businesses - or rather the wealth of their owners. However, it is certainly not the case that the majority of the UK's 6 million businesses would need to be valued. Around $60 \%$ of these are sole proprietorships or partnerships with no employees, and many of these are unlikely to have significant market value (Section 2). In terms of how businesses could be valued, it appears that income-based valuation approaches could serve as a key input to the valuation of a majority - potentially four in five private businesses. Valuing businesses without a consistent profit stream will require a combination of approaches, potentially involving the valuation of underlying assets. This may be challenging in industries such as Professional and Scientific Activities, and Financial Services, where there is a high share of intangible assets. However, even where there are hard cases, there is reason to be optimistic: evidence from the top 100 fastest-growing tech firms suggests that the majority of loss-making firms have received funding from venture capital, providing an observable transaction that could serve as input to the valuation.

It is inevitable that some business owners will find it difficult to pay a wealth tax out of their business income, as Loutzenhiser and Mann (2020) document. However, empirical evidence suggests that many incorporated businesses, and large businesses in particular, also have a substantial amount of retained earnings - reserves that could be used to finance a wealth tax (Section 4). Nine in ten profitable companies have at least some retained earnings to draw upon. Some business owners will not need to draw upon this liquidity to pay the tax, as the amount they already derive in salary and dividends will suffice. Whether or not business owners are able to draw upon retained earnings depends on how much influence they have over how funds are used, and there is a concern that this may be difficult for taxpayers who are just one of many

\footnotetext{
${ }^{1}$ Throughout the paper, I define a 'private business' as one whose shares are not traded publicly on an exchange market. I do not purposely restrict my analysis to businesses taking any particular legal form. That is, I include both incorporated businesses ('companies') as well as unincorporated businesses (including 'sole traders' and 'partnerships'). However, throughout the paper, I draw on evidence from a number of sources, many of which exclude certain types of business. In each case, I will make it clear which types of business are represented in the statistics. In Appendix A I provide a short description of each data source which explains which businesses are covered and, briefly, how the data are constructed.
} 
shareholders in a business. However, evidence suggests that these are minority cases with $78 \%$ of unlisted companies controlled by no more than 2 shareholders.

Farming businesses are a specific source of concern for some who worry that farming incomes are low relative to the value of the land, and that farmers may therefore find it difficult to pay a wealth tax. In their empirical analysis, Loutzenhiser and Mann (2020) identify farmers as being over-represented in low liquidity groups. In Section 5, I hone in on which types of farm are most likely to be brought within the scope of a wealth tax and the extent of liquidity issues farmers face. The focus is on businesses engaged in agricultural production ('farming businesses'), rather than the land-owning population as a whole, as only limited evidence is available on the latter. Where possible, I include analysis of the liquidity issues faced by landowners more broadly.

Evidence from the Farm Business Survey suggests that around $58 \%$ of farm businesses would be covered by a wealth tax with an exemption threshold of $£ 500,000$ per individual. Taxpaying farm businesses would be concentrated in the General Cropping and Cereal sectors, and businesses located in the South East will be the most likely to be taxed.

Overall, it is true that income yields on land are low relative to other assets. However, the total return to farmland is comparable to other assets, as farmland experiences strong capital growth relative to other types of property. In terms of funding wealth tax payments, the problem is therefore one of liquidity, rather than of solvency. Though data limitations prevent an in-depth analysis of liquidity constraints at this time, it would appear as though while a minority of farms that are more likely to be taxed do make low or negative profits, a significant percentage are more than capable of financing wealth tax payments out of business income. Cereal farm businesses would make up the largest percentage of taxed farming businesses under a wealth tax starting at $£ 500,000$, with around three quarters being taxed. Among these, $13 \%$ make a loss, and yet $20 \%$ make profits in excess of $£ 100,000$.

The remainder of the paper is structured as follows. Section 2 gives a sense of scale by presenting statistics on the UK business population. Section 3 provides evidence on which businesses could be challenging to value using income-based and asset-based approaches alone. Section 4 provides evidence on which businesses are most likely to face liquidity constraints, the amount of liquidity held as retained earnings, and multi-shareholder issues that could affect a business owner's ability to extract income to pay the tax. Section 5 zooms in on farming businesses specifically, presenting evidence on the characteristics of farms that are likely to be taxed, and potential liquidity constraints. Finally, Section 6 concludes. 


\section{Extent of private businesses in the UK}

There were 6 million businesses operating in the UK private sector at the start of 2020 (BEIS, 2020). This is a comprehensive estimate of the total UK business population. It includes incorporated business (both private and publicly listed), and unincorporated businesses (sole proprietorships and ordinary partnerships), whether or not registered for VAT and/or PAYE.

The majority of these businesses (59\%) are sole proprietorships (unincorporated businesses) with no employees (see Table 1). Many of these businesses are unlikely to have an open market value which brings them within the scope of a wealth tax for any reasonable exemption threshold, though this depends on the remaining wealth of the owner. As a result, the number of businesses which might need to be valued under a wealth tax is likely to be substantially lower than the headline number of businesses. This also applies to partnerships, $75 \%$ of which have no employees. Indeed, under the extreme assumption that no business without any employees would be covered by a wealth tax, the number of businesses which might potentially require valuation falls by $76 \%$ from 6 million to 1.4 million.

However, it is not true that all sole proprietorships and partnerships have little value. Most partnerships are small, with 60\% having turnover of less than $£ 100,000$ in 2011-12 (OTS, 2014). However, $5 \%$ had turnover in excess of $£ 1$ million. Large partnerships are predominantly professional firms and mechanisms through which 'City' financial arrangements operate.

TABLE 1: NUMBER OF BUSINESSES, BY NUMBER OF EMPLOYEES AND LEGAL STATUS (START OF 2020) Number of businesses

\begin{tabular}{l|rrr}
\hline Number of employees & Companies & Ordinary partnerships & Sole proprietorships \\
\hline None & 945,545 & 310,895 & $3,311,335$ \\
1 to 9 & 850,845 & 86,475 & 219,600 \\
10 to 49 & 187,955 & 15,145 & 8,750 \\
50 to 249 & 34,930 & 1,025 & 185 \\
$250+$ & 7,795 & 35 & 5 \\
All & $2,027,070$ & 413,575 & $3,539,875$
\end{tabular}

Notes: 'Employees' excludes owners and partners, regardless of whether they receive a salary. 'Companies' includes both listed and private corporations. 'Ordinary partnerships' consists of businesses run by two or more self-employed people. This excludes limited liability partnerships, which are included as companies.

Source: BEIS, Business Population Estimates, 2020.

Private businesses are rather more challenging to value than publicly listed companies whose shares are traded on the open market. As such, it is important to establish how many private businesses there are in the UK, before we can understand how many of these might need to be valued. Companies House provide estimates of the number of incorporated businesses by listing status. At the end of March 2020, there were 4.35 million incorporated companies on the Companies House register (Companies House, 2020). This figure is around twice the estimated number of companies reported in the Business Population Estimates. There are four key reasons for this (BIS, 2012). First, the Business Population Estimates are based on the ONS Interdepartmental Business Register (IDBR), which only includes actively trading companies, ${ }^{2}$ whereas Companies House includes dormant companies. Second, the IDBR excludes companies set up for purposes not directly related to economic activity, such as the protection of names, or

\footnotetext{
2 Those with VAT/PAYE activity, excluding dormant companies on the Companies House register. The Business Population Estimates contain an estimate of the size of the active, unregistered (for VAT/PAYE) business population, but do not include inactive companies. See BIS, 2012, for further details.
} 
clubs and societies. It is not clear whether such companies have sufficient value to be relevant in the event of a wealth tax. Third, the IDBR combines information from Companies House and other government departments to create 'enterprises' which may combine multiple company registrations. These enterprises would presumably be valued as a single entity for tax purposes, and it is therefore the ONS figure which is relevant for understanding the magnitude of valuation for a wealth tax. Finally, the IDBR excludes companies that are registered in the UK but are only active overseas. The latter would still be taxed under a wealth tax on the worldwide assets of UK residents, and so the ONS statistics will undercount the number of businesses that could be taxed.

Private limited companies account for over $96 \%$ of all corporate body types on the Companies House register; public limited companies account for just $0.1 \%$. The majority of companies will therefore not have a readily available publicly listed share price. Moreover, there are a significant number of dormant private companies, representing $18-20 \%$ of the Companies House register, which are not included in the Business Population Estimates (BIS, 2012). These may still hold substantial assets.

Overall, it is not possible to conclude how many businesses would need to be valued without data on the wealth of business owners, or at least on the value of the business. However, it is certainly not the case that it would be necessary to value all of the UK's 6 million businesses. The majority of these (at least 60\%) are very small, with no employees, and many of these are unlikely to be taxed. In practice though, some sole proprietors will be very wealthy, while some companies with several employees will have owners whose wealth is not above the wealth tax threshold. 


\section{Valuing private businesses}

Where a private business could come within the scope of a wealth tax, either because the business itself has significant value, or because the business owner has a significant amount of wealth held outside of the business, it is necessary to estimate how much the business is worth in order to calculate the tax liability. Various approaches to constructing a proxy for the open market value of private businesses exist and are discussed at length in Daly and Loutzenhiser (2020) and Ryan (2020). In this section, I discuss the extent to which some of the problems associated with these valuation approaches exist in practice, and for which businesses.

\subsection{Income-based valuation}

Income-based approaches to valuation, which involve calculating the net present value of earnings generated by business assets, require an observable and consistent income stream (Ryan, 2020). If there are a substantial number of businesses for which this is unavailable, this increases the need to adopt alternative valuation approaches instead of or in combination with income-based approaches. In this section I document evidence on the types of business which may be difficult to value due to a lack of, or inconsistent, profits. The generation of profits also matters from a liquidity perspective, which is discussed in more detail in Section 4.

Unfortunately, granular information on the distribution of profits across different industries and businesses is scarce. The research consultancy BVA BRDC reports findings from a survey of 4,500 Small to Medium Enterprises (SMEs) in the 'SME Finance Monitor' every 6 months. ${ }^{3}$ The survey represents UK businesses with fewer than 250 employees. According to the survey, 82\% of businesses with 1-9 employees, and $87 \%$ of businesses with more than 10 employees, made a profit in the most recent 12-month trading period (BVA BRDC, 2020). Only 13-18\% made a loss or broke even. These figures exclude sole proprietorships, which are less likely to be within the scope of a wealth tax. This suggests that the majority of businesses do have some profit on which the valuation could be based. However, these statistics are based on a snapshot of the business population, and do not provide information on the volatility of profits. This is important, as it is difficult to value businesses using income-based approaches if their income fluctuates widely from year to year. These figures should therefore be interpreted as an upper bound on the percentage of business to which income-based valuation approaches could be applied.

Figure 1 shows median profit and loss by number of employees, as well as the percentage of SMEs making a loss or breaking even. Unfortunately, it is not possible to analyse the distribution of profits by business value to see what profits are made by businesses that are likely to be covered by a wealth tax. However, it is clear to see that while many larger businesses make a substantial profit, losses can be large among the minority of businesses making a loss. Income capitalisation approaches are unlikely to be a feasible valuation solution for these businesses.

\footnotetext{
${ }^{3}$ SMEs are businesses with fewer than 250 employees. See Appendix A for further details on this survey.
} 


\section{FIGURE 1: MEDIAN PROFIT/LOSS AMONG SMES MAKING A PROFIT/LOSS (£OOOS)}

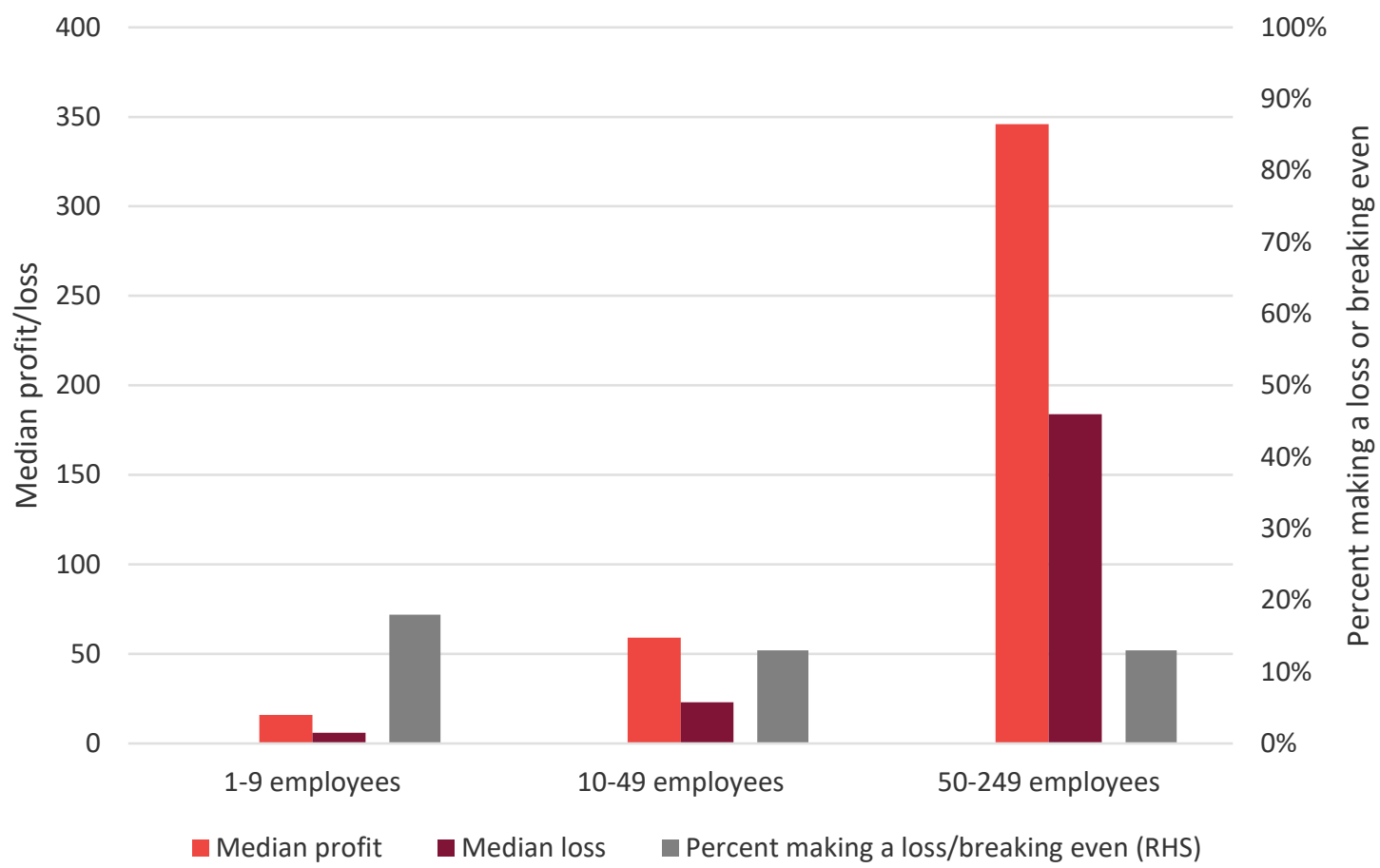

Source: BVA BRDC, 2020.

At the very top end, the Sunday Times Top Track 100 provides evidence on the profits earned by the 100 biggest private UK companies, defined on the basis of sales. ${ }^{4}$ Measured using earnings before interest, taxes, depreciation, and amortization (EBITDA), only $1 \%$ made a loss, while $29 \%$ made profits in excess of $£ 250$ million. ${ }^{5}$ Valuation of these businesses using incomebased methods may be feasible, and this evidence suggests that the problem of applying incomebased approaches to valuation is decreasing in scale as businesses get larger. As noted in Daly and Loutzenhiser (2020), valuing larger private businesses is typically easier anyway, as they are more readily comparable with listed companies. Overall, this suggests that the problem of valuing private businesses will be less acute the higher the wealth tax threshold. The higher the threshold, the fewer are businesses that would need to be valued, and the higher the percentage of businesses for which income-based approaches to valuation will be appropriate.

\section{Start-ups}

The presence of start-ups matters from a valuation perspective for at least two reasons. First, they are more challenging to value than established businesses with a regular profit stream. By definition, they have no past profits to observe, and many may not generate a profit for several years to come. Second, the number of start-ups created each year determines how many firms will need to be valued from scratch in each valuation period. This is relevant to an annual wealth tax, rather than a one-off. Under a one-off wealth tax, all businesses would have to be valued from scratch, once. Under an annual wealth tax, the challenge of valuing businesses will decline over time as many businesses can base their value on what they were worth the year before. However, for start-ups and high growth businesses (discussed in the subsequent section), this is not the case. Of course, if start-ups are less valuable than established businesses (or their

\footnotetext{
${ }^{4}$ See Appendix A for information on how this list is compiled.

5 The Sunday Times Top Track 100 Research Report (2020).
} 
owners less wealthy), the proportion of start-ups requiring valuation would be lower than for established businesses.

ONS Business Demography Statistics (2019a) provide some insight into the start-up rate in the UK, and how this varies by industry. The statistics cover all businesses operating in the UK who are registered for VAT and/or PAYE and have VAT and/or PAYE activity during the reference year. This includes all legal statuses (incorporated and unincorporated, private and publicly listed etc.). They estimate the 'birth rate' in each industry, defined as the proportion of active businesses that began trading in the reporting year.

In 2018 , the birth rate was $13 \%$. This masks considerable heterogeneity across industries. Figure 2 shows the birth rate by industry group. Transport and storage (inc. postal) saw the highest birth rate, at $17.8 \%$, followed closely by business administration and support services (17.2\%) and retail (16.9\%). This is illustrative of which industries may be most implicated by the challenges surrounding the valuation of start-ups. However, the majority of these businesses are sole proprietorships, and many will be outside the scope of a wealth tax as a result of having little market value. We should therefore interpret $13 \%$ as an upper bound on the percentage of businesses that would need to be valued from scratch under an annual wealth tax. Of course, under a one-off wealth tax, all businesses will be valued from scratch, and start-ups will only be a special case to the extent that they are harder to value due to having no observable profit stream.

\section{FIGURE 2: BUSINESS 'BIRTH RATE' BY INDUSTRY GROUP (2018)}

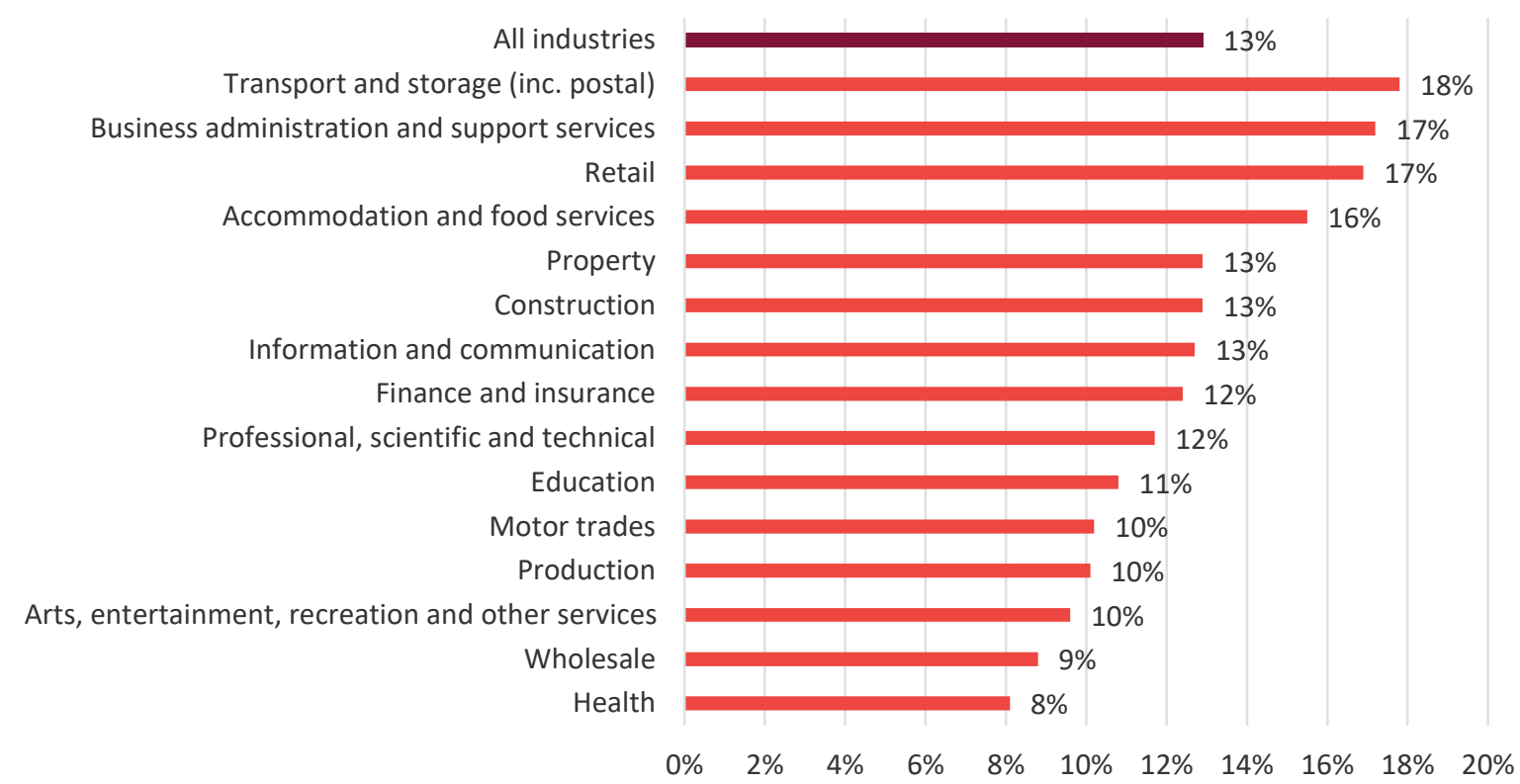

Notes: 'Birth rate' measures the percentage of active businesses in each industry that began trading in the reference year.

Source: ONS, Business Demography Statistics, 2019a.

\section{High-growth companies}

Just as start-ups could be difficult to value using income capitalisation methods, with highgrowth companies it could take several years before a consistent income stream can be observed. Companies in the 'tech' industry are a perfect example of this. Companies in this sector could be difficult to value for two reasons. First, they may fail to make a profit for several 
years. Second, much of their value can be held in the form of intangible assets, which are difficult to value (discussed in Section 3.2).

The Sunday Times Tech Track 100 lists the 100 UK private tech companies with the fastest growing sales over the last 3 years. ${ }^{6}$ Among these, $61 \%$ made a loss in the latest financial year. ${ }^{7}$ Of these loss-making companies, $55 \%$ were backed by venture capital, private equity firms, or business angels. Indeed, 79\% of companies on the list had secured funding from these sources and $48 \%$ were majority owned by PE/VC firms. This presents an opportunity for valuation: private equity investments produce an observable transaction on which the value of the firm could be based. For example, the digital banking services provider 'Revolut', ranked at number 1 in 2019, was valued at $\$ 1.7$ billion in 2018 and was reported to be raising an additional $\$ 500$ million that could increase its value to $\$ 5$ billion. Valuing companies based on private equity trade deals could be useful, particularly for firms without an observable profit stream as was the case with Revolut in 2019. However, basing wealth tax valuations on this information would affect incentives to secure private equity investment.

\subsection{Asset-based valuation}

An alternative approach to valuation is based on valuing the underlying assets and liabilities owned by the business. For tangible assets, this is reasonably straightforward. However, businesses also hold assets which are intangible, such as Intellectual Property and software. These are inherently harder to value (Ryan, 2020), and are omitted from company accounts. Ryan (2020) discusses various valuation methods which could be applied to intangible assets. In this section, I quantify the importance of intangible assets in the economy and their concentration in certain industries and businesses.

The ONS produce estimates of the flow of investment in intangible assets as a supplement to the UK National Accounts (ONS, 2019b). Their methodology for calculating the amount of investment expenditure in intangible assets is based on the approach developed by Corrado, Hulten and Sichel (2005) and Goodridge, Haskel and Wallis (2014). Intangible assets include software and databases; research and development; mineral exploration and evaluation; entertainment, literary and artistic originals; design; financial product innovation; branding; organisational capital; and firm-specific training. Since 1998, investment in intangible assets has accounted for around $50 \%$ of total investment on average, suggesting that a significant amount of business value is held in the form of intangible assets (ONS, 2019b).

We can also compare investment in intangible assets as a share of total investment by industry (Fig. 3). In the Professional and Scientific Activities industry, 71\% of investment is in intangible assets, and the share is almost as high in Financial Services (70\%) and Information and Communication (66\%). Unsurprisingly, businesses in the Electricity, Gas and Water Supply, Construction, and Agriculture, Forestry and Mining industries have the lowest intangible intensity.

\footnotetext{
${ }^{6}$ See Appendix A for information on how this list is compiled.

${ }^{7}$ The Sunday Times Tech Track 100 Research Report (2020).
} 


\section{FIGURE 3: INVESTMENT IN INTANGIBLES AS A SHARE OF TOTAL INVESTMENT, BY INDUSTRY}

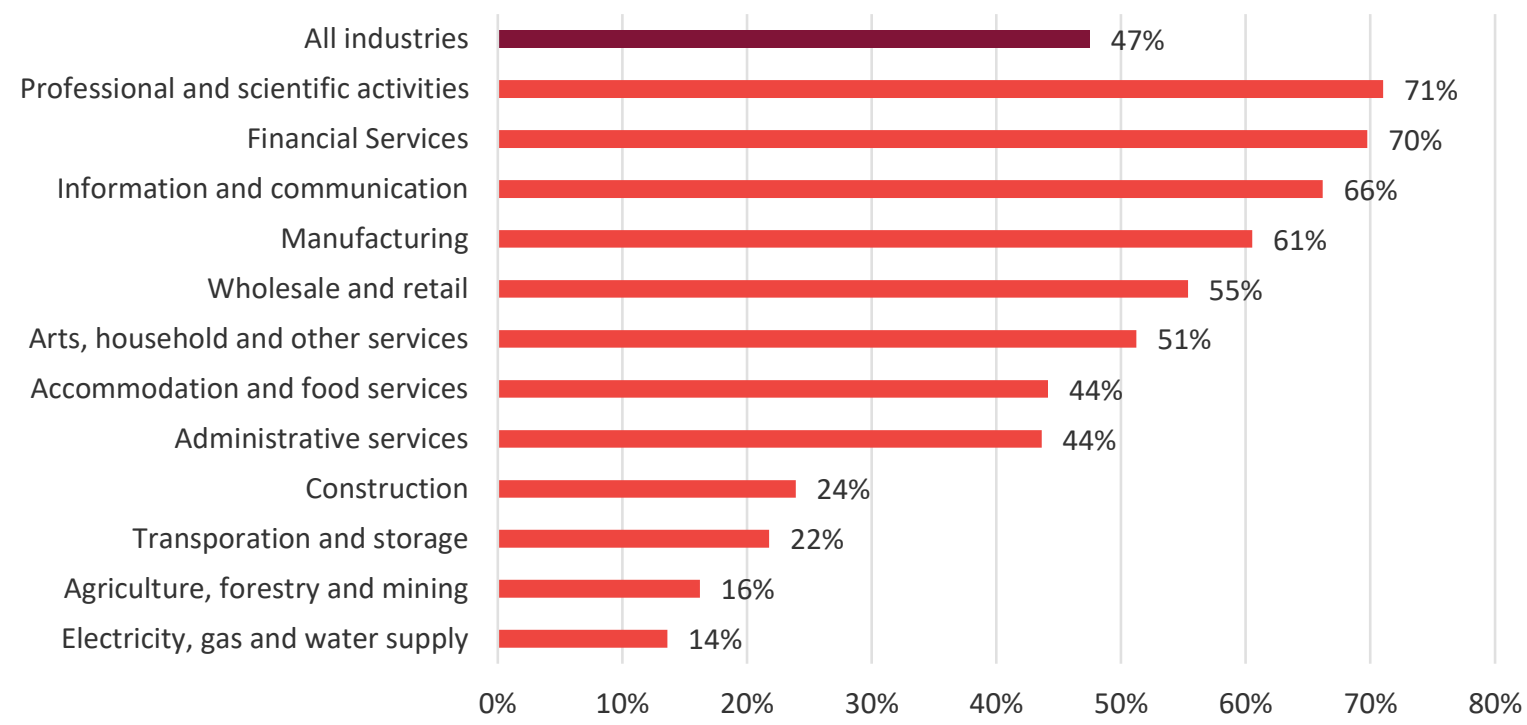

Notes: 'Intangible assets' includes software and databases; research and development; mineral exploration and evaluation; entertainment, literary and artistic originals; design; financial product innovation; branding; organisational capital; and firm-specific training.

Source: ONS, "Developing experimental estimates of investment in intangible assets in the UK: 2016", 2019b.

While measures of intangible intensity indicate which industries have the highest concentrations of potentially hard-to-value intangible assets, this does not mean that businesses in these industries could not easily be valued using alternative methods, such as income-based approaches. The hardest businesses to value are likely to be those with a high share of intangible assets and a limited or inconsistent profit stream. Unfortunately, there is little information on how many businesses satisfy this combination of characteristics.

Keilloh et al. (2015) provide some information on ownership of intangible assets, based on a survey of 1,501 unlisted UK companies. ${ }^{8}$ The data are not completely representative of the population of UK unlisted companies, as medium and large companies are deliberately overrepresented. Moreover, response rates were low, at just 38\%, due to difficulties in contacting companies and a high non-cooperation rate among those successfully contacted. The survey asks whether companies own any intangible assets, including goodwill, logos, know how, copyright, brands, trademarks, patents, software, domain names/websites, and accreditation. According to the survey, $24 \%$ of companies own intangible assets, and ownership was positively correlated with turnover, profits, and retained earnings.

The most common types of intangible asset owned by unlisted companies are goodwill (59\%), logos $48 \%$ ), and know how (46\%). Just $8 \%$ of unlisted companies report owning patents, and $2 \%$ own software. However, ownership of different classes of intangible asset varies by turnover and sector. Just under a quarter of companies with turnover in excess of $£ 1$ million own Intellectual Property, for example. Companies in the Information and Communications sector were most likely to own Intellectual Property (39\%) and other intangible assets (22\%) followed closely by companies in Professional, Scientific \& Technical Activities (23\% and 21\%). Unfortunately, the survey does not provide any measure of the value of these intangible assets, or how this varies with profitability.

\footnotetext{
${ }^{8}$ See Appendix A for more information on this data source.
} 


\section{Liquidity issues}

A second concern regarding the taxation of business owners is that many businesses may not generate enough profit to pay for a wealth tax out of business income. Private business wealth is relatively illiquid, and one may worry that an inability to fund the tax payment could force the disposal of some of these businesses if payment were required immediately and borrowing were not possible. Loutzenhiser and Mann (2020) show that business owners are over-represented in low liquidity groups. This motivates the provision of additional evidence on the income generated by businesses.

Before exploring the extent of liquidity issues, it is important to highlight two facts. First, the amount of tax that has to be paid depends not only on the value of the business, but on the total wealth of the business owner. Second, the ability of the business owner to pay the tax depends not only on income they derive from business(es) they own, but on their total income (and liquid wealth). Loutzenhiser and Mann (2020) provide evidence on how the total income of business owners compares to their wealth. In this paper, I focus on income generated by the business itself.

\subsection{Profits}

The profits generated by a business are one indicator of the owner's ability to pay. Also important are how much of these profits are distributed to shareholders, and the degree of control the relevant owner (as one of potentially multiple shareholders) has over this. As discussed in Section 3.1, there is little empirical evidence available on the proportion of private businesses making profit among high-value businesses specifically.

BVA BRDC (2020) report that $82 \%$ of SMEs made a profit in the latest 12 -month reporting period. Figure 4 illustrates how the percentage of all SMEs making a profit, including those with no employees, varies by sector. The Health sector contained the highest percentage of SMEs making a profit, at $86 \%$. Hotels and Restaurants saw the smallest percentage of SMEs making a profit, at 74\%. Across all SMEs, the proportion of businesses making a loss is not insignificant: at least $18 \%$ of SMEs have no business income from which they could finance a wealth tax. However, it is not clear how many of these businesses would be taxed.

Figure 5 shows the median level of profit/loss earned by SMEs making a profit/loss (BVA BRDC, 2020). It is worth pointing out that these statistics will be affected by the number of firms fluctuating from profit to loss in each industry year-on-year, as this will affect which business is at the median among those making a profit/loss. ${ }^{9}$ With this caveat in mind, Business in the Real Estate, Renting and Business Activities sector are not only among the most likely to make a profit (85\%), but they also earn the highest level of median profits $(£ 10,000)$ when they do. Businesses in the Hotels and Restaurants sector are the least likely to make a profit and have the highest median loss of $£ 6,000$. However, Hotels and Restaurants have one of the highest death rates, with $16 \%$ of businesses ceasing in a given year (ONS, 2019a). Loss-making businesses are more likely to go out of business, and so it is likely that many of these businesses would be irrelevant for a wealth tax. While this paints a picture of which sectors may face difficulties in funding wealth tax payments, these figures are likely to be far from representative of businesses that would actually face a wealth tax. This is because it is not clear how wealthy the owners of these businesses are, nor what the relevant tax threshold would be.

\footnotetext{
${ }^{9}$ In the absence of additional data, it is not possible to provide a more detailed breakdown of the distribution of profits and losses by industry.
} 


\section{FIGURE 4: PERCENTAGE OF SMES MAKING A PROFIT, BY SECTOR}



Notes: Includes businesses with zero employees (sole proprietorships or single director companies). Source: BVA BRDC, 2020.

\section{FIGURE 5: MEDIAN PROFIT/LOSS AMONG SMES MAKING A PROFIT/LOSS (£OOOS)}

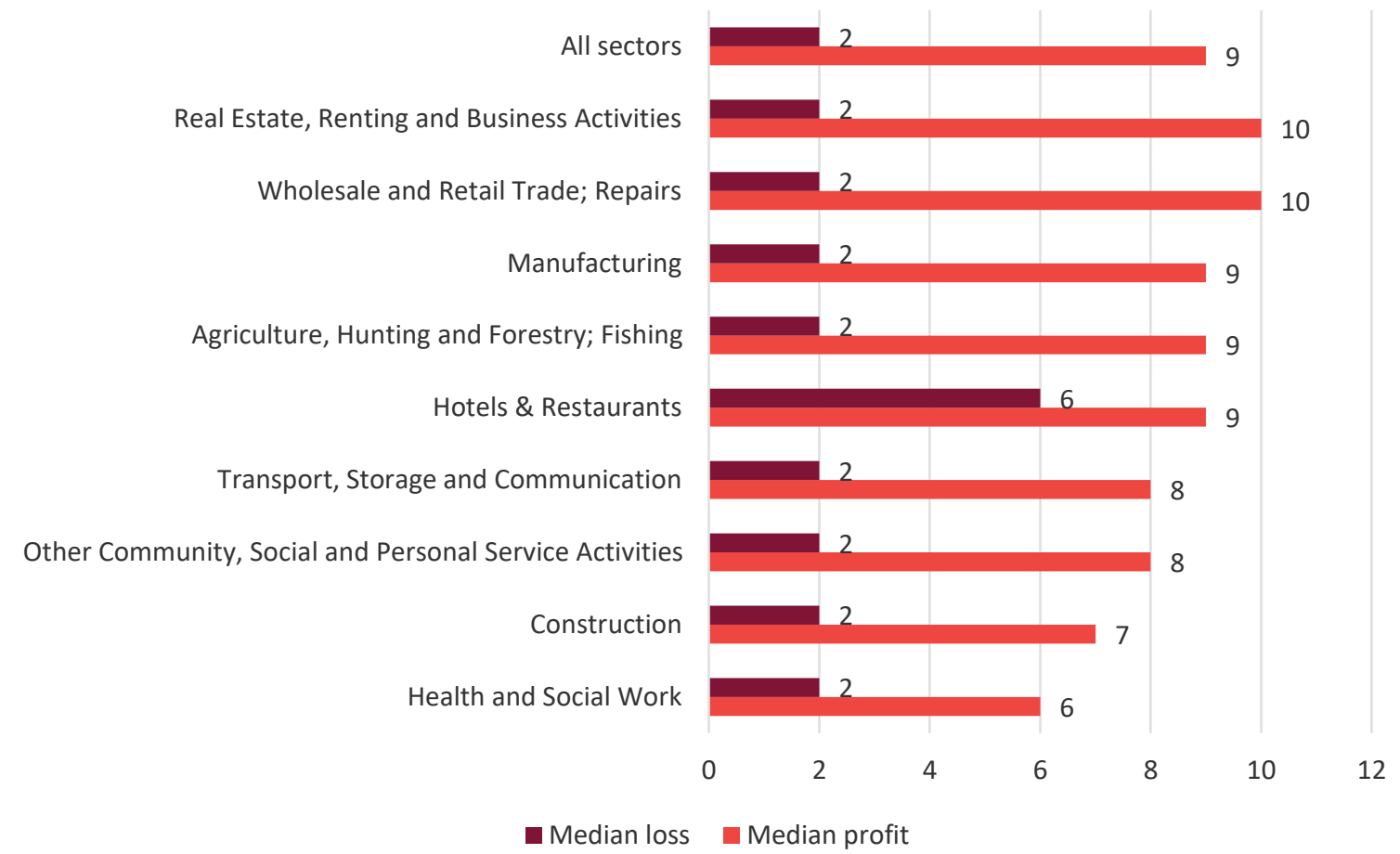

Notes: Includes businesses with zero employees (sole proprietorships or single director companies). Source: BVA BRDC, 2020.

\subsection{Retained earnings}

Wealth tax payments are not made directly out of profits generated within the business, but out of the income or wealth of the business owner, which may include any salary or dividends received from the business. Loutzenhiser and Mann (2020) look at the extent to which business owners would be liquidity constrained on the basis of income they currently receive from all 
sources, including salaries and dividends received from the business. Defining 'liquidity constrained' as having net income and liquid wealth that amounts to less than $10 \%$ of illiquid wealth above the wealth tax threshold, they find that around 72,000 business owners ( $2 \%$ of taxpayers) would be liquidity constrained with a $£ 500,000$ exemption threshold. With a threshold of $£ 2$ million, 20,000 business owners (10\% of taxpayers) would be liquidity constrained. The rising share reflects the fact that as the threshold rises, the share of business owners in the taxpaying population also increases.

These statistics are indicative of liquidity issues among the business owning population. However, to fully understand the extent of liquidity problems, we need to know not only how much business owners current/y receive in salaries and dividends, but how much more they are able to extract from the business in order to pay the tax. In this section, I briefly review the evidence on how businesses distribute profits between shareholders (dividends) and the business (retained earnings), and what this can tell us about how much liquidity is 'missing' from statistics which focus on the income business owners currently receive. Of course, the earnings of the business itself constrain how much income the owner can receive. However, this may not be the only constraint. Where there are multiple shareholders, this can limit the degree of control each individual owner has over the amounts paid out. Ownership structure is discussed further in Section 4.3.

Some businesses are 'deliberately illiquid' in that they have the capacity to pay higher dividends than they actually do. There are various legitimate reasons for wishing to retain profits, such as maintaining cash reserves for a rainy day, or for future investment. Tax incentives also motivate what has been termed 'moneyboxing' - the deliberate retention of earnings which are later distributed as capital upon liquidation, rather than as dividends which are typically taxed at a higher rate (Burges Salmon, 2016; Advani and Summers, 2020). ${ }^{10}$ This means that we cannot judge the extent of liquidity problems exclusively on the basis of dividend and salary payments we currently observe, as these payments are ultimately a choice.

Keilloh et al. (2015) provide evidence on the distribution of profits in their survey of unlisted companies, which represents incorporated businesses only and does not include sole proprietorships or partnerships. According to the survey, $45 \%$ of companies paid a dividend to shareholders in the last full accounting period. Of the companies making a profit, $70 \%$ paid dividends to shareholders. This suggests that a significant proportion of profit-making business retain some profits in the business. In fact, $79 \%$ have retained earnings, i.e. profits that have not been distributed to shareholders. Table 2 reports the level of retained earnings accumulated up to the end of the last full accounting year among profit-making companies, by the number of employees. Companies with higher levels of employment - that are more likely to be taxed retained more: $64 \%$ of those with at least 10 employees had retained in excess of $£ 100,000$. This suggests that companies likely to be drawn into the wealth tax base could have substantial reserves of retained earnings to draw on to finance the tax.

While retained earnings may provide additional liquidity for many business owners, it is inevitable that there will be some taxed businesses that make little or no profit, and have no retained earnings to draw upon. However, Table 2 suggests that among profit-making companies ( $64 \%$ of companies) with at least one employee, at most $31 \%$ have less than $£ 10,000$ in retained earnings, and at most $9 \%$ have none at all. This is before taking into account dividends and salaries that business owners are already paid. For business owners who do are not able to pay the tax out of business income, their ability to pay will hinge on this income plus any remaining income and liquid wealth they have.

${ }^{10}$ Capital distributed on liquidation attracts Capital Gains Tax, which typically results in a lower rate of tax for the recipient than if the profits had been distributed as dividends. 
TABLE 2: LEVEL OF RETAINED EARNINGS EARNED CUMULATIVELY UP TO THE END OF THE LAST FULL ACCOUNTING YEAR, BY NUMBER OF STAFF

\begin{tabular}{|c|c|c|c|c|c|c|c|c|}
\hline Retained earnings & $\begin{array}{l}\% \text { Zero } \\
\text { director } \\
\text { employees }\end{array}$ & non- & $\begin{array}{l}\% \quad 1-4 \\
\text { director } \\
\text { employees }\end{array}$ & non- & $\begin{array}{l}\% \quad 5-9 \\
\text { director } \\
\text { employees }\end{array}$ & non- & $\begin{array}{l}\% \quad 10+ \\
\text { director } \\
\text { employees }\end{array}$ & non- \\
\hline$£ 0$ & & $14 \%$ & & $8 \%$ & & $9 \%$ & & $7 \%$ \\
\hline$£ 1$ to $£ 10,000$ & & $37 \%$ & & $23 \%$ & & $14 \%$ & & $4 \%$ \\
\hline$£ 10,000$ to $£ 20,000$ & & $10 \%$ & & $16 \%$ & & $9 \%$ & & $4 \%$ \\
\hline$£ 20,000$ to $£ 30,000$ & & $5 \%$ & & $8 \%$ & & $10 \%$ & & $3 \%$ \\
\hline$£ 30,000$ to $£ 50,000$ & & $4 \%$ & & $7 \%$ & & $13 \%$ & & $9 \%$ \\
\hline$£ 50,000$ to $£ 100,000$ & & $7 \%$ & & $8 \%$ & & $9 \%$ & & $10 \%$ \\
\hline More than $£ 100,000$ & & $9 \%$ & & $19 \%$ & & $48 \%$ & & $64 \%$ \\
\hline $\begin{array}{l}\text { Share of all unlisted } \\
\text { companies }\end{array}$ & & $39 \%$ & & $35 \%$ & & $10 \%$ & & $16 \%$ \\
\hline
\end{tabular}

Notes: Includes all companies that made a profit in the last accounting period. Excludes those who did not know the amount of retained earnings, or whether they had retained earnings, and those who refused (11\% in total).

Source: Keilloh et al., 2015.

\subsection{Ownership structure}

Ownership structure has implications for both valuation and liquidity issues. The value of shares held in a business depends partly on the degree of control conferred on the owner. Shareholders with a minority stake in the business may have little say in how the business is run, and the sum of minority-owned share values is likely to be lower than if those shares were held by a single owner with a majority stake. Ownership structure also affects liquidity issues, as the ability of an individual to extract dividends from the business will depend on the entitlements bestowed on them as a result of owning shares, and the number of other shareholders that have a say. ${ }^{11}$ The extent of valuation and liquidity problems arising from multi-shareholder issues will depend crucially on how many businesses have complex ownership structures. This is the focus of this section.

Companies incorporated in the UK are required to declare their beneficial owners (or 'Persons of Significant Control', PSC). An individual is classified as a PSC if they hold more than $25 \%$ of the shares in a company; or hold more than $25 \%$ of voting rights; or hold the right to appoint/remove board directors'; or the right or exercise significant influence or control over the company through other means or via a trust. PSCs need not be individuals; they can be corporate bodies. However, unless intermediate corporate bodies are incorporated outside of the UK, it is, in principle, possible to trace upwards to identify the ultimate owners of a company.

UK companies have 1.13 beneficial owners on average, with 1 being the most common number (Global Witness, 2018). Where no owner controls more than $25 \%$, it is not necessary for companies to declare beneficial owners, and out of the 4.19 million companies on the register at the time $9 \%(335,000)$ declare that they have no beneficial owner. This number represents a lower bound on the number of companies where multi-shareholder issues may arise, though there will of course be more companies where no single shareholder controls more than $50 \%$. On the other hand, there may be a number of companies where a husband and wife, or multiple

\footnotetext{
${ }^{11}$ Moreover, businesses need not be owned directly by individuals. They may instead be owned by other
} companies, or via trusts. 
members of the same family, own a controlling share between them. Analysing the extent of multi-shareholder issues without taking into account family connection could therefore understate the proportion of companies from which owning households could extract dividends to pay a wealth tax.

According to Keilloh et al. (2015), 92\% of surveyed unlisted companies identified themselves as close companies, defined as having 5 or fewer shareholders, or where directors collectively own more than $50 \%$ of shares. The percentage of unlisted companies with different numbers of shareholders is illustrated in Figure 6. On this basis, it appears that multi-shareholder issues would not be a significant problem in the majority of cases.

Keilloh et al. (2015) also provide information on the nature of control granted via shares. A majority of companies with shareholders (89\%) issued full voting shares, which would presumably give owners some say over how profits are distributed, including the amount of dividends paid out. A minority (2\%) issued preference shares and other types of shares. Director-shareholders are extremely common: $92 \%$ say that company directors have overall control of the company. The remainder are controlled by investors who worked (2\%) or did not work (3\%) for the company, or a parent, stakeholder or holding company (1\%).

\section{FIGURE 6: NUMBER OF SHAREHOLDERS}

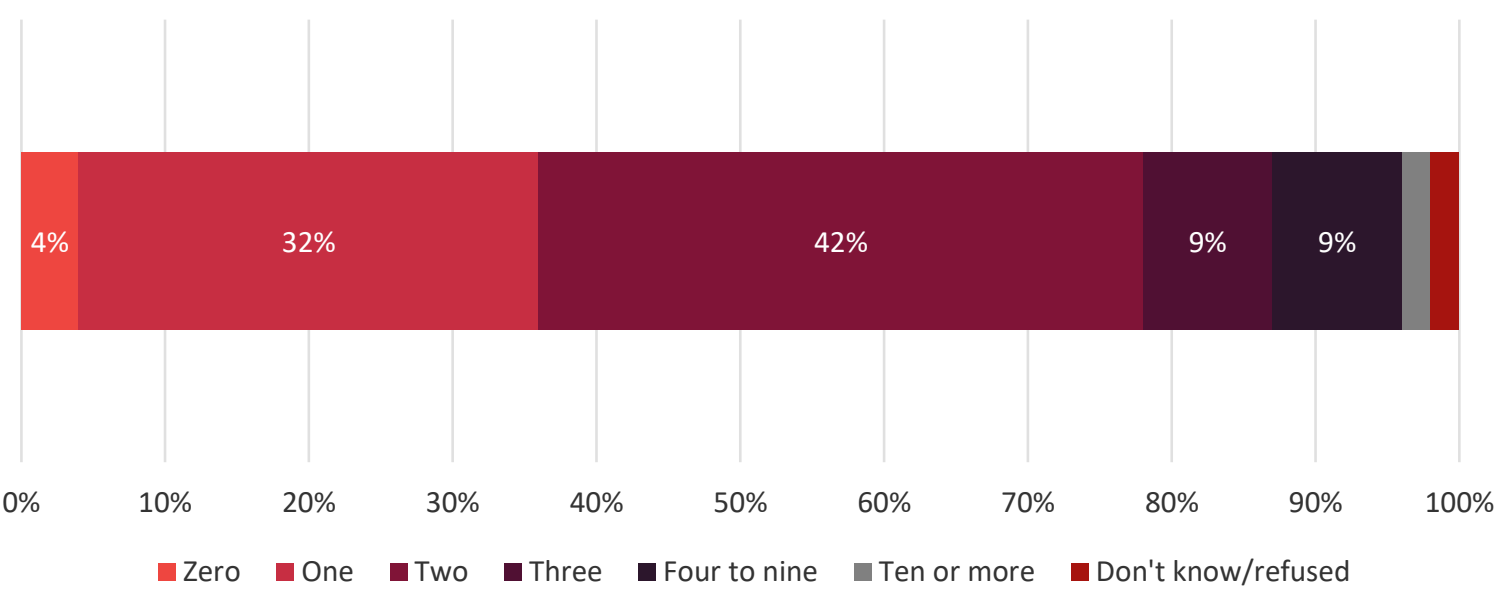

Notes: Includes unlisted companies only.

Source: Keilloh et al., 2015.

Information on the ownership structures of high-value companies to which a wealth tax is highly likely to apply can be found in the Sunday Times Top Track 100 and Top Track 250. According to the Top Track 100, which lists the 100 biggest UK private companies defined on the basis of sales, $34 \%$ of companies are majority owned by entrepreneurs or their founders, and a further $26 \%$ are owned by the family of the founder (including subsequent generations). These families will arguably have significant control over how these businesses are run and how the funds are used. A further 34 are owned by private equity firms, and it is the private equity investor who will pay the tax on these business assets. The Top Track 250, which lists the next-biggest 250 UK private companies, ${ }^{12}$ reports a similar distribution of ownership structures: $35 \%$ of companies are majority owned by entrepreneurs or founders; $28 \%$ are family-owned; and $24 \%$ are owned by private equity or venture capital firms.

In sum, the evidence suggests that while there will be some hard cases, multi-shareholder issues are unlikely to be relevant to the vast majority of private businesses.

${ }^{12}$ Eligibility criteria for the Top Track 250 differ slightly from those for the Top Track 100 . See Appendix A for additional information. 


\section{Farming businesses}

Here, a 'farm business' is a business that generates at least some of its income from agriculture. As with any other business, a farm business need not own the land on which it farms. There are therefore two groups of potential taxpayers we must consider in the context of farms: those who own and run the business, generating an income from agriculture and other business activities; and those who own the land. For owner-occupied farms, these groups coincide, and the value of the business includes the value of the land. For tenanted farms, the land is held by the landlord who generates an income yield in the form of rent.

Farmers - those who own and run agricultural farming businesses - are over-represented in low liquidity groups, suggesting that these individuals are indeed likely to find it difficult to pay the tax (Loutzenhiser and Mann, 2020). As with other private businesses, agricultural business assets are illiquid, and often highly valuable (particularly agricultural land). In Section 5.1, I document evidence on which types of farming business are most likely to have to pay a wealth tax. Section 5.2 explores which farm businesses could face liquidity problems. Assessing the extent of liquidity problems faced by landowners more broadly - including those who do not farm the land themselves - is much more challenging. There is limited data relating the value of land to the income it generates, except for owner-occupied agricultural businesses. Where possible, I draw on additional sources of data to understand the situation of the landowning population more broadly.

There are 219,000 farm holdings in the UK (Defra, 2020a). The total value of these holdings depends on the definition used to assess the value of agricultural property. As discussed at length in Clark and Fu (2020), the market value of agricultural land - the value that would be reached in a hypothetical transaction between a vendor and purchasers - differs from the agricultural value of the land, which can be understood as the value of the land if its future use were restricted to farming activities alone, rather than other potential uses such as development. The market value of farmland has departed from agricultural value in recent years, as discussed further in Section 5.1. Savills (2020) estimate the total market value of agricultural land assets in the UK at $£ 216$ billion, suggesting that there is substantial wealth available to be taxed.

Meanwhile, Aggregate Farm Business Income (FBI) - defined as net profit before deducting the imputed cost of unpaid labour - is estimated at $£ 5.3$ billion (Defra, 2020a). ${ }^{13}$ This includes income from non-agricultural activities the business engages in, such as recreation, tourism, solar energy, conferences, as long as the business produces at least 25,000 Euros of standardised agricultural output. FBI also includes direct (public) payments, including all payments made under Common Agricultural Policy (CAP) schemes. These amounted to $£ 3.3$ billion in 2019, a startling 62\% of FBI. Compared to a total agricultural land value of $£ 216$ billion, this implies a yield of $2.45 \%$, much of which is not directly derived from agricultural production. Note that this yield is before taking into account income from non-agricultural activities among landowners (not farmers) whose land is either not used for agriculture at all, or whose land is only farmed by tenant farmers. It also ignores any rent that these landowners receive. As a result, this aggregate yield is neither representative of the return on owning land, nor of the return on agricultural business assets, as the latter will not include the value of land for all farmers.

\footnotetext{
${ }^{13}$ See https://assets.publishing.service.gov.uk/government/uploads/system/uploads/attachment_data/ file/557605/fbs-definintions-4oct16.pdf for details on how FBI is measured.
} 
In the subsequent sections I draw on evidence from the Farm Business Survey, which sheds light on the value of agricultural farming businesses in England and the income they generate from both agricultural and non-agricultural activities. ${ }^{14}$ The survey covers farming businesses with at least 25,000 Euros of annual standardised output, representing 57,100 farming businesses in total. Smaller, excluded farms, are less likely to be within the scope of a wealth tax, though it is possible that the owners of these farming businesses own other valuable assets, in which case some of these farms may be within scope. Excluded from the survey are landowners who do not themselves produce agricultural output (but who may rent the land to tenant farmers). Unless otherwise indicated, the statistics presented in the subsequent analysis are therefore representative of the value of agricultural farming businesses, and the ability of their owners to pay a wealth tax, rather than the circumstances of all landowners.

\subsection{Which farm businesses might be in scope?}

Ultimately, the number farm business owners having to pay a wealth tax depends on the number whose total wealth is above the wealth tax threshold. Some owners may hold other valuable assets, or indeed own multiple farms. However, the value of each farming businesses provides some indication of how many farmers are likely to be taxed, especially if few farmers have little additional wealth (see Section 5.3 for evidence on who owns farm businesses).

In the Farm Business Survey, 'net worth' is defined as the value of assets held by the business (including land if applicable, machinery etc.) less liabilities. Net worth is measured on a conservative market value basis. ${ }^{15}$ This is not necessarily the value on which we may wish to base a wealth tax (see Clark and Fu, 2020, for a discussion of alternative values), and it may be slightly lower than the market value at which the business could actually be sold. This is particularly true for the value of land, as the 'hope' value arising from the development potential of the land is not taken into account. According to this measure, total wealth among commercial farming businesses in England amounts to $£ 104$ billion, which excludes the value of land that is not owned by the business itself. In the subsequent sections I discuss which farm businesses are most likely to have sufficient value to be covered by a wealth tax.

Farmland owned by landlords accounted for 37\% of farmed land area in England in 2016 (Defra, 2018). The exclusion of this land from the net worth statistics matters for at least two reasons. First, estimates of the number of high-value farming businesses will understate the number of high-value agricultural land holdings. Second, in the analysis that follows, estimates of the distribution of net worth across different regions or farm types could reflect different mixes of tenanted/owner-occupied farming. For example, if General Cropping farms are more likely to be owner-occupied than Grazing Livestock farms, then it is not surprising that General Cropping farm businesses tend to be worth more than Grazing Livestock businesses, that do not own the land on which the animals graze, though this is of course not the only explanation for this difference. This is not an issue if the question we are interested in is which farmers will have to pay the tax, and whether they can pay. What it does not enable us to answer is how many

\footnotetext{
${ }^{14}$ Details on which farms are covered and the survey methodology can be found in Appendix A. Similar data exist for other nations of the UK: see https://www.gov.uk/government/collections/farm-businesssurvey for more information.

${ }^{15}$ The specific guidance is "All assets should be valued at conservative market values. Market Value is the estimated value for which an asset should exchange on the date of valuation between a willing buyer and a willing seller, after proper marketing, where the parties had acted knowledgably and prudently..."Hope" value resulting from the possibility of future residential or commercial development of the land should be excluded in arriving at valuations. However, due attention should be paid to local market conditions and to any particular features of the farm which may significantly enhance or diminish its likely sale value relative to the average for farms of that size and type."
} 
landowners as a whole will be taxed on the value of farms they own, and their ability to pay, which will depend on the rent they receive from the tenant farmers.

Overall, $58 \%$ of farming businesses $(33,100)$ have net worth in excess of $£ 1$ million per farm. This suggests that most farming business owners are likely to be covered by a wealth tax with an exemption threshold of $£ 1$ million or below if the entire value of the business is attributed to a single individual. Fewer will be covered if the value of the business is divided between multiple owners, such as a couple who own the farming business jointly. Given that $58 \%$ of all farming businesses are worth more than $£ 1$ million, this suggests that at least this many farm businesses would be covered by a wealth tax with a threshold of $£ 500,000$ even if all farms were jointly owned by a couple, a reasonable approximation of the household composition of farm business owners. ${ }^{16}$

\section{Net worth by farm type}

Some types of farming business are more valuable than others, suggesting that not all business owners are as likely to be taxed. Figure 7 shows the average net worth of farming businesses by type. General Cropping businesses are the most valuable, with an average net worth of $£ 2.9$ million. Second most valuable are Cereal businesses, worth $£ 2.6$ million on average. The value of these businesses is driven in part by their size and land quality (Defra, 2020b). Horticulture and Less Favoured Area (LFA) Grazing Stock businesses are the least valuable on average at $£ 0.7$ million and $£ 0.9$ million, respectively.

\section{FIGURE 7: AVERAGE NET WORTH (£M PER BUSINESS), BY FARM TYPE}



Notes: Net worth includes all assets owned by the farm business, including land (where applicable), machinery etc., net of liabilities. Net worth is measured on a conservative market value basis. See Section 5.1 for details.

Source: Defra (2020b), Balance sheet analysis and farming performance, England 2018/19 (Farm Business Survey).

In line with the statistics on average net worth, General Cropping and Cereals feature the highest shares of businesses in high net worth brackets, with Dairy and Mixed businesses showing a similar distribution (Fig. 8). This suggests that owners of General Cropping, Cereals,

\footnotetext{
${ }^{16} 67 \%$ of farm businesses are run by a single household, among which the average number of working age adults is 1.58 (Defra, 2016). Applying this average to farm businesses comprised of more than household, we find that $29 \%$ of businesses are comprised of two households (3.16) adults, and $4 \%$ are three or more households (around 5 adults). On average, this implies 2.2 adults per farm business.
} 
Dairy, and Mixed businesses are most likely to be brought within the scope of a wealth tax. Owners of Horticulture and Pigs and Poultry businesses are least likely to be taxed, with 33\% and $35 \%$, respectively, worth less than $£ 250,000$.

Not only are Cereal business owners the most likely to be taxed, the number of high value Cereal businesses is much higher than for any other farm type (Fig. 9). In total, $18 \%$ of businesses worth more than $£ 1$ million are Cereal producers, while $12 \%$ are in Lowland Grazing Livestock. The income generated by these businesses in particular will be of interest when considering ability to pay among business owners who could face a wealth tax (as discussed in Section 5.2).

\section{FIGURE 8: DISTRIBUTION OF BUSINESS NET WORTH, BY FARM TYPE}

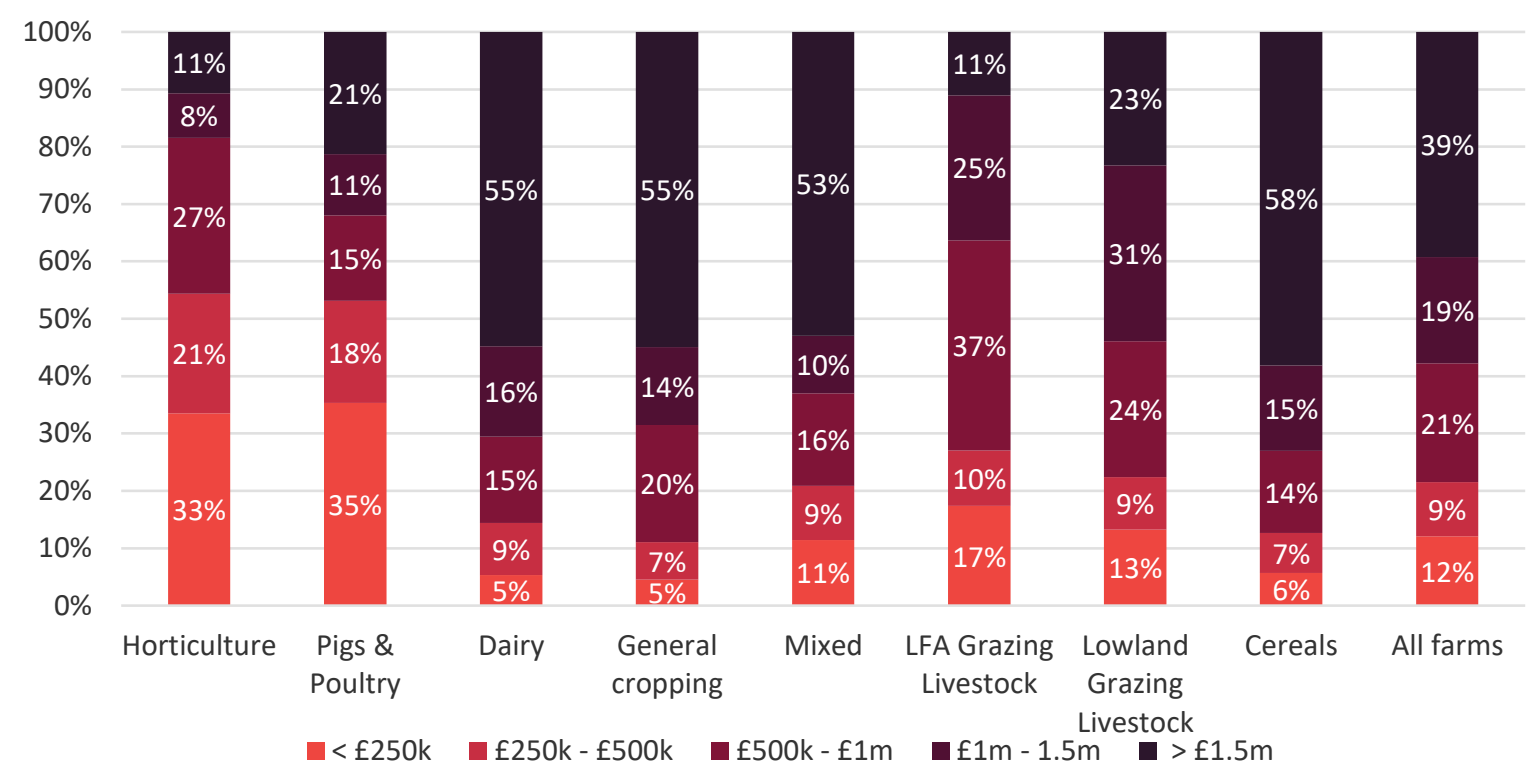

Notes: Net worth includes all assets owned by the farm business, including land (where applicable), machinery etc., net of liabilities. Net worth is measured on a conservative market value basis. See Section 5.1 for details.

Source: Defra (2020b), Balance sheet analysis and farming performance, England 2018/19 (Farm Business Survey).

\section{FIGURE 9: NUMBER OF BUSINESSES ('000) BY NET WORTH AND FARM TYPE}

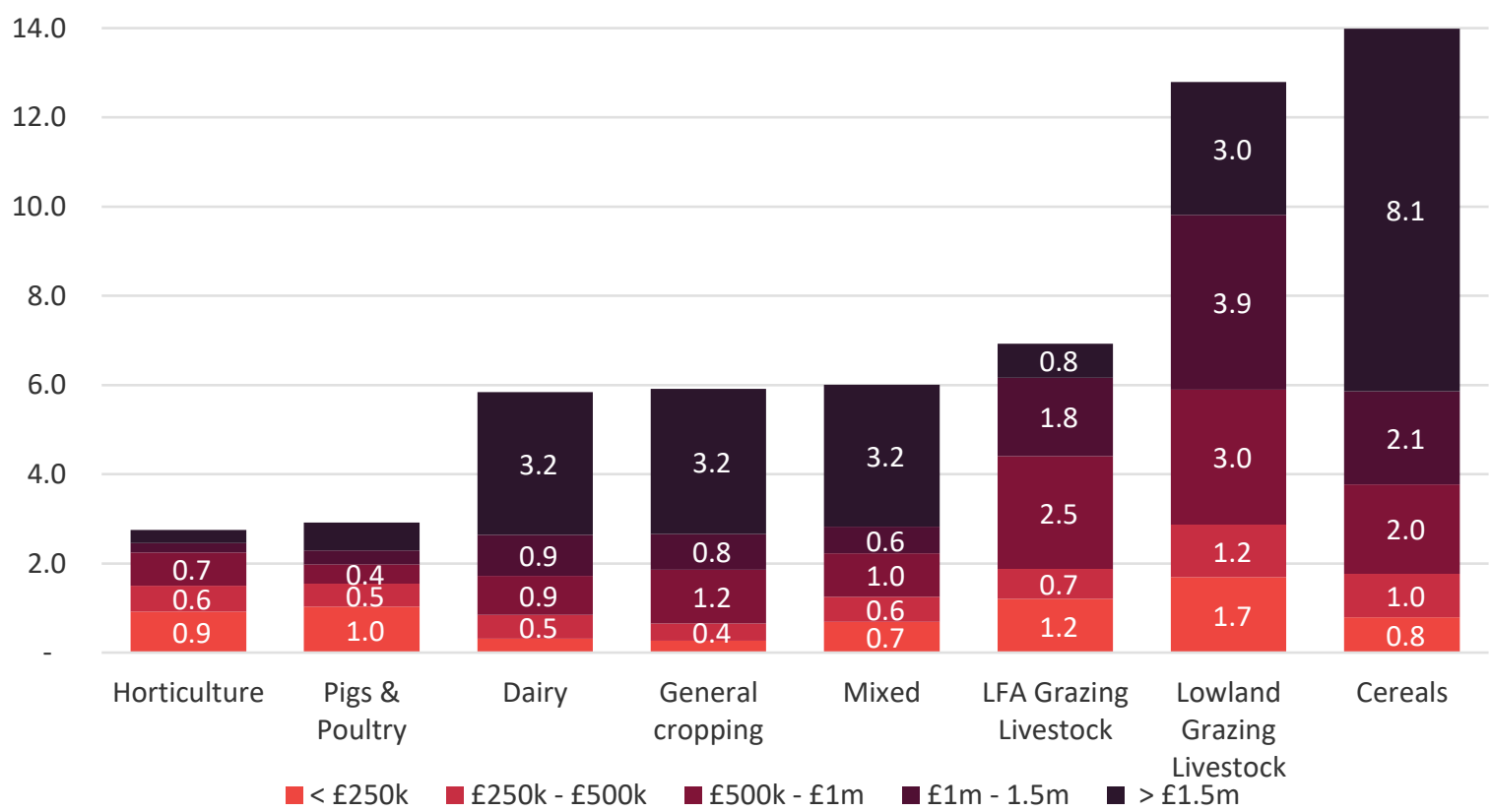

Notes: Net worth includes all assets owned by the farm business, including land (where applicable), machinery etc., net of liabilities. Net worth is measured on a conservative market value basis. See Section 5.1 for details.

Source: Defra (2020b), Balance sheet analysis and farming performance, England 2018/19 (Farm Business Survey). 


\section{Net worth by geographical region}

The average commercial farming business in England is worth $£ 1.8$ million. This varies significantly across regions, as Figure 10 shows. Businesses in the East of England are worth a hefty $£ 2.5$ million, on average, based on conservative market value. This compares to just $£ 1.1$ million in the North West. This suggests that business owners in the East and South East of England are most likely to pay a wealth tax, and pay the most.

However, the variation in net worth partly reflects differences in tenure, rather than differences in the value of agricultural land, since it is the assets owned by the business that are valued. Tenanted farming businesses do not include the value of land in their net worth. This is one reason why average net worth is lower in the North East, which has a high prevalence of tenanted farms (Defra, 2018). It is therefore not necessarily the case that farms in the North East are less likely to be subject to a wealth tax, but rather that those paying the tax on the value of the land are not the ones farming it.

\section{FIGURE 10: AVERAGE NET WORTH (EM PER FARMING BUSINESS), BY REGION}

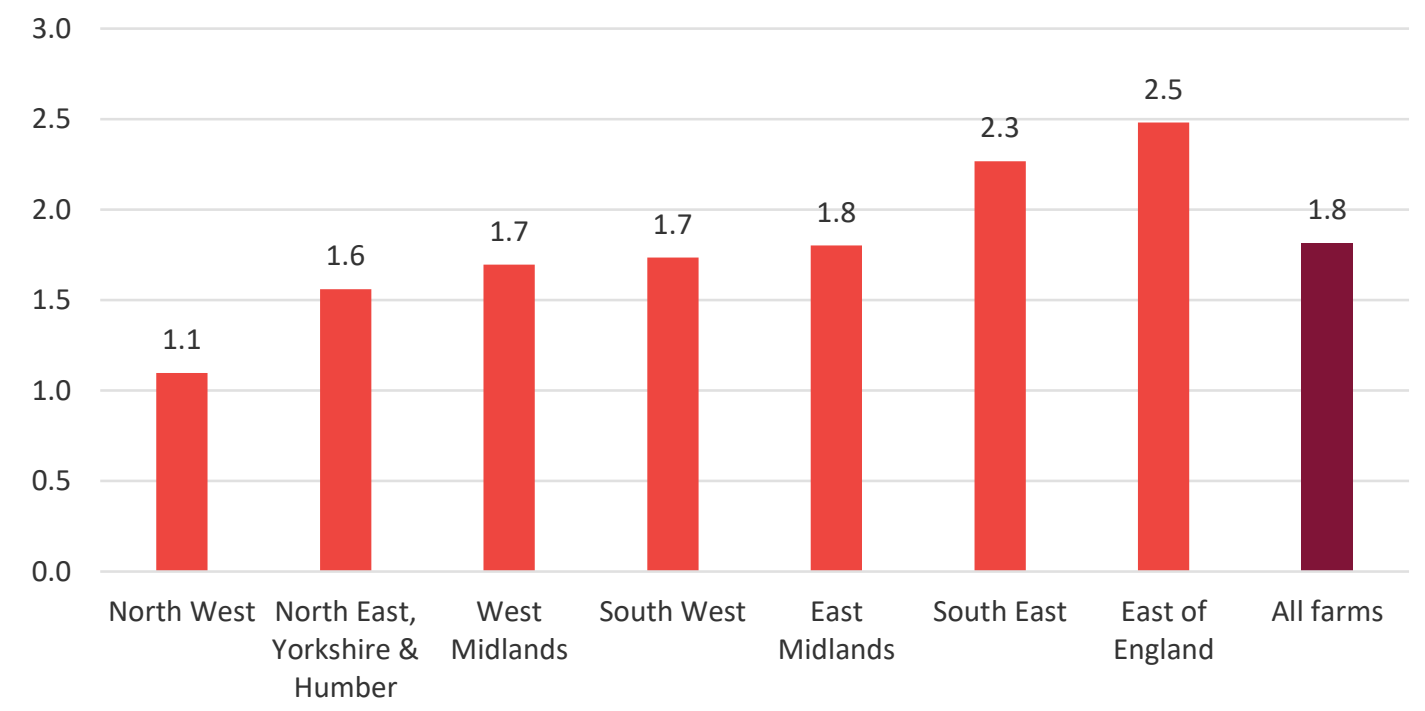

Notes: Net worth includes all assets owned by the farm business, including land (where applicable), machinery etc., net of liabilities. Net worth is measured on a conservative market value basis. See Section 5.1 for details.

Source: Defra (2020b), Balance sheet analysis and farming performance, England 2018/19 (Farm Business Survey).

The region with the highest proportion of farming businesses worth more than $£ 1.5$ million is the South East, at $55 \%$ (Fig. 11). In this region, 88\% of businesses are worth more than $£ 500,000$. In all regions except the North West, North East and Yorkshire, at least $50 \%$ of businesses are worth in excess of $£ 1$ million. This suggests that the majority of farm business owners in most regions are likely to have to pay a wealth tax with an exemption threshold of $£ 1$ million or below if the business is attributed to a single owner, or $£ 500,000$ or below if the value of the business is divided among a couple. 
FIGURE 11: DISTRIBUTION OF NET WORTH, BY REGION

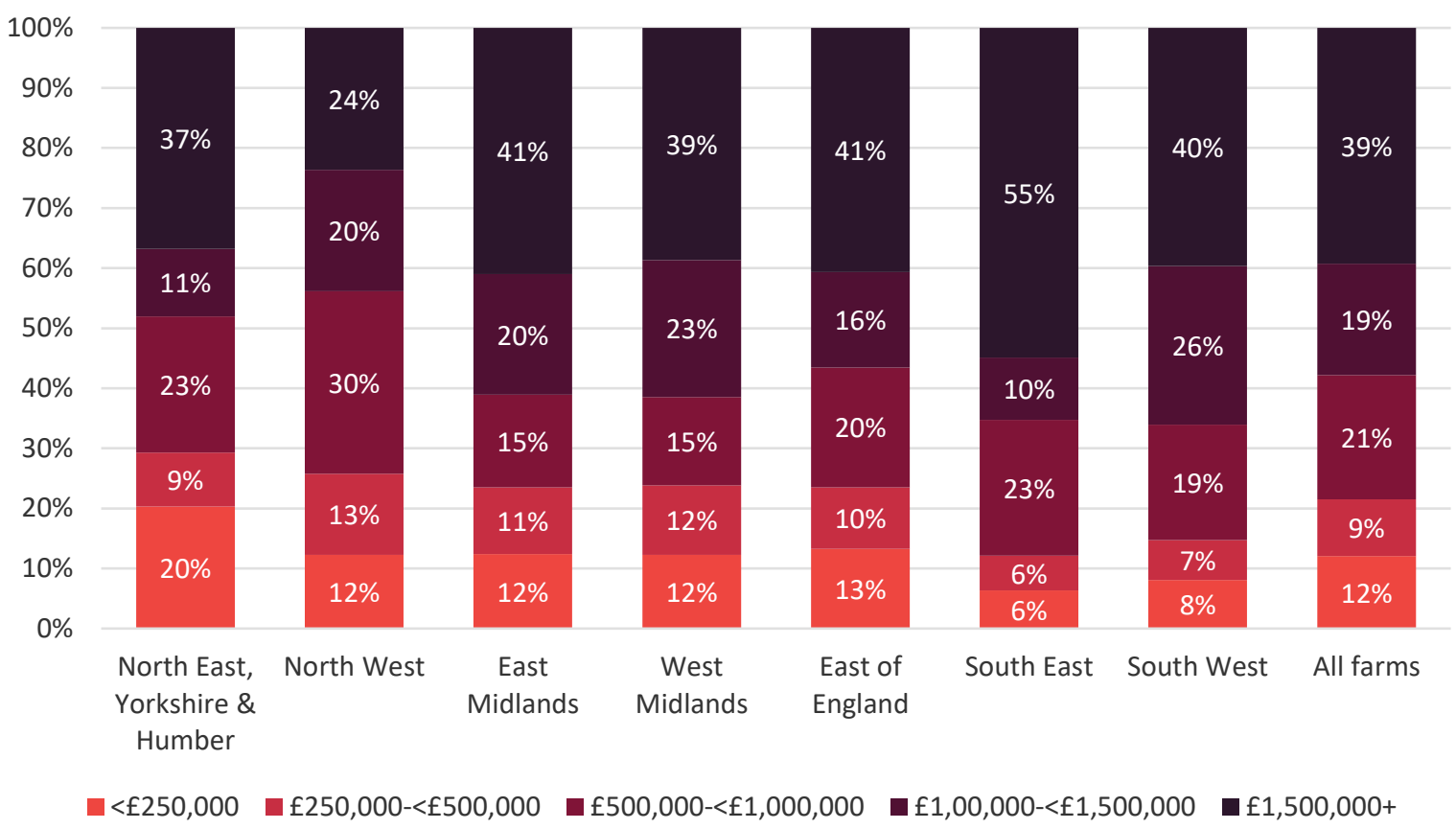

Notes: Net worth includes all assets owned by the farm business, including land (where applicable), machinery etc., net of liabilities. Net worth is measured on a conservative market value basis. See Section 5.1 for details.

Source: Defra (2020b), Balance sheet analysis and farming performance, England 2018/19 (Farm Business Survey).

\subsection{Do farms generate enough income to pay a wealth tax?}

Farming businesses in the UK generate $£ 5.3$ billion in FBI (net profit), including income from non-agricultural activities such as recreation, tourism, solar energy, retail, and subsidy payments (Defra, 2020a). Though this is not especially high relative to an estimated market value of agricultural land of $£ 216$ billion (Savills, 2020), it excludes income going to landlords as well as income generated from non-agricultural activities that is not earned by agricultural businesses (e.g. income from solar energy where the owner does not farm any of the land).

Direct payments (subsidies) amount to almost two thirds of this total profit, with the CAP Basic Payment being the largest contributor, though this is set to change in a post-Brexit UK. These payments are made to the owners of farm businesses, rather than directly to landlords. However, there is some evidence suggesting that such payments are capitalised into the rents paid by tenant farmers (Defra, 2018), and so are likely to account for a significant proportion of the yield landlords receive on their agricultural land holdings.

Land values have decoupled from the agricultural productivity of the land in recent years (Savills, 2020). There are a number of explanations for this, including a growing trend of nonfarmer purchasers who comprised 53\% of buyers in 2019 (Savills, 2020). Many of these purchasers invest for reasons of lifestyle and investment security, rather than for commercial farming. Additional influential factors include diversification of farming incomes, expectation of planning gain, and buyer sentiment (Savills, 2020). It is also possible that some of the tax advantages bestowed upon agricultural businesses (e.g. via Agricultural Property Relief for inheritance tax) is capitalised into the value of agricultural land. These trends contribute to concerns that agricultural land may not provide sufficient income to fund a wealth tax.

To assess the potential liquidity problems faced by the landowning population as a whole, it is important to recognise the different ways in which land can generate a return. Savills (2015) 
estimate that though income yields on agricultural land are not particularly large on average, capital growth prospects are generally higher than for alternative property assets, and are relatively more stable. The average income yield on top quality agricultural land was roughly $1.5 \%$ in 2015 , but capital growth was estimated to average $8 \%$ over a 5 -year period (Savills, 2015). By contrast, alternative property investments such as prime offices earned a much higher income yield at just under $5 \%$, but faced 5 -year capital growth of just $2 \%$.

Table 3 illustrates the total annualised return on farmland (including capital growth) compared to other assets, according to Savills (2019) market research. Over the longer term, returns on land (including income from non-agricultural activity, and capital growth on the land) are not particularly low relative to other asset, and indeed are not necessarily as low as agricultural income statistics alone suggest. These total returns are driven by capital growth, rather than by income yields. The issue from the perspective of financing a wealth tax is, on the whole, one of liquidity rather than solvency. A potential solution to liquidity problems is that individuals borrow against their capital growth.

TABLE 3: TOTAL RETURN ON FARMS COMPARED TO OTHER ASSETS

\section{Annualised return over}

\begin{tabular}{|c|c|c|c|c|}
\hline Asset & 1 year & 5 years & 10 year & 20 years \\
\hline Let land & $1.6 \%$ & $6.3 \%$ & $7.6 \%$ & $10.9 \%$ \\
\hline Farming top 25\% (arable) & $-0.3 \%$ & $3.7 \%$ & $8.9 \%$ & $8.0 \%$ \\
\hline Forestry & $13.9 \%$ & $13.7 \%$ & $15.8 \%$ & $10.2 \%$ \\
\hline Let residential 7\% & $7.0 \%$ & $9.5 \%$ & $7.2 \%$ & $11.4 \%$ \\
\hline Commercial property & $9.6 \%$ & $10.9 \%$ & $5.7 \%$ & $8.5 \%$ \\
\hline Equities & $11.8 \%$ & $9.2 \%$ & $5.6 \%$ & $5.9 \%$ \\
\hline Gilts & $1.8 \%$ & $3.3 \%$ & $5.9 \%$ & $6.0 \%$ \\
\hline Gold & $0.4 \%$ & $-5.5 \%$ & $6.1 \%$ & $6.9 \%$ \\
\hline
\end{tabular}

Notes: Let land includes farmland, residential and commercial assets on rural estates and farms. 'Farming top 25\%' represents high performing arable farming, taking into account the capital value of land and tenant's capital, but excluding residential assets. Net income and tenant's capital is derived from Defra/FBS data and the land value from Savills Farmland Value Survey.

Source: Savills (2019), derived from multiple sources: Savills databases, MSCI, Defra, KITCO.

Turning to farm business owners specifically, rather than the landowning population as a whole, the Farm Business Survey allows for a more detailed analysis of potential liquidity problems. Using data from the Wealth and Assets Survey, Loutzenhiser and Mann (2020) find that farmers are over-represented among the group of potential taxpayers classified as having 'low liquidity' - defined as having a ratio of net income plus liquid wealth to net illiquid wealth above different thresholds of less than 10\%. The Farm Business Survey provides evidence on the distribution of FBI (profit) among different types of farming business, and across businesses in different regions.

FBI includes income from non-agricultural activities, though businesses without significant agricultural output are excluded. It does not include income earned by members of farming households that is not derived from the business, such as from another job. As such, it does not fully represent the business owner's ability to finance a wealth tax. In Section 4.1, I describe the total household income of farming households for the subset of businesses owned by a single household. However, in this section, only business income (including diversified income) is included. 


\section{Profits by farm type}

There is considerable heterogeneity in FBI across and within farm types, as illustrated in Table 4. Overall, $21 \%$ of farm businesses in England made a loss, and yet $15 \%$ of businesses made profits in excess of $£ 100,000$. Forthcoming analysis of microdata will enable a direct comparison of profits to net worth. However, we can consider how profits vary by farm type, which is correlated with net worth (Section 5.1). Among General Cropping and Cereal businesses - the most likely to be taxed, only $9 \%$ and $13 \%$ make a loss, respectively. However, $29 \%$ (20\%) of farms of these types make profits in excess of $£ 100,000$. It is possible that those making a loss would not be taxed anyway, if they are at the lower end of the net worth distribution among farms of this type. Moreover, even if loss-making farms are valuable enough to be taxed, Table 3 suggests that it would be possible to borrow against the respectable capital growth earned on agricultural land. This evidence suggests that while some farm business owners may indeed face liquidity constraints, a significant proportion will be more than capable of paying a wealth tax. Appendix B shows a similar picture across regions.

TABLE 4: FARM BUSINESS INCOME, BY FARM TYPE

\begin{tabular}{|c|c|c|c|c|}
\hline Farm type & $\begin{array}{l}\text { Average FBI } \\
\text { (£000/farm) }\end{array}$ & $\%$ making a loss & $\begin{array}{l}\text { \% making } \\
>£ 100 k \text { in } \mathrm{FBI}\end{array}$ & $\begin{array}{l}\text { Average net worth } \\
\text { (£m per farm) }\end{array}$ \\
\hline Cereals & 67 & $13 \%$ & $20 \%$ & 2.6 \\
\hline General Cropping & 106 & $9 \%$ & $29 \%$ & 2.9 \\
\hline Dairy & 80 & $13 \%$ & $29 \%$ & 1.9 \\
\hline $\begin{array}{l}\text { Grazing Livestock } \\
\text { (Lowland) }\end{array}$ & 13 & $32 \%$ & $2 \%$ & 1.2 \\
\hline $\begin{array}{l}\text { Grazing Livestock (Less } \\
\text { Favoured Area) }\end{array}$ & 16 & $32 \%$ & $2 \%$ & 0.9 \\
\hline Specialist Pigs & 30 & $28 \%$ & $20 \%$ & 1.2 \\
\hline Specialist Poultry & 75 & $31 \%$ & $21 \%$ & 1.2 \\
\hline Mixed & 46 & $19 \%$ & $17 \%$ & 2.0 \\
\hline Horticulture & 52 & $16 \%$ & $14 \%$ & 0.7 \\
\hline All Types & 50 & $21 \%$ & $15 \%$ & 1.8 \\
\hline
\end{tabular}

Notes: Farm Business Income (FBI) includes income from agricultural activities and diversified activities such as recreation, tourism, solar energy, retail, and subsidy payments, as long as the business also produces agricultural output. It excludes income going to landlords. Net worth includes all assets owned by the farm business, including land (where applicable), machinery etc., net of liabilities. Net worth is measured on a conservative market value basis. Source: Defra (2020b) Balance sheet analysis and farming performance, England 2018/19 (Farm Business Survey); Defra (2020c), Farm Accounts in England 2018/19 (Farm Business Survey).

\subsection{Who owns farm businesses?}

As with private businesses, it is not the financial situation of the farm that ultimately determines whether the farm is covered by the tax, nor the extent of liquidity issues. It is the financial situation of the owner. Defra (2016) provides evidence on the income and household composition of farm households from the Farm Business Survey. ${ }^{17}$ Information is collected for the household of the principal farmer from each business, and not from the households of other farmers or business partners. The data capture information on all income received by farming households, from the business as well as from non-business activities. By the latter, I do not

\footnotetext{
${ }^{17}$ Details on households covered and data collection methods can be found in Appendix A.
} 
mean income from diversified activities within the business, such as the use of land for retail or commercial activities, but income derived from other jobs, investments, or pensions.

Ability to pay the tax is not solely contingent on income generated by the farming business, as $32 \%$ of household income is derived from other sources, on average. Farm household incomes are 14\% higher than the average UK household income (Fig. 12). Farm households received an average gross income of $£ 46,700$ in $2014 / 15$, compared to $£ 41,000$ for the average UK households. A quarter of farming households have an income of no more than $£ 16,600$, slightly more than the percentage of households with this level of income in the UK as a whole. That said, a smaller fraction of this income needed for living expenses than for the average UK taxpayer, as farming households will typically not be paying rent or a mortgage on their farmhouse. Among the UK population, $21 \%$ of gross household income is spent on rent and mortgage payments. For comparison, Figure 12 shows UK household income after the deduction of rent and mortgage payments.

Average household income among farm households consists of $£ 31,900$ derived from the principal farmer's share of farm business income, $£ 13,400$ of off-farm income earned by the farmer and spouse, and $£ 1,400$ accruing to other household members. Around half of farm households received at least $50 \%$ of their non-farm income from unearned sources, including investments and pensions, while $28 \%$ of households received at least $50 \%$ of non-farm income from work in other sectors or professions.

\section{FIGURE 12: HOUSEHOLD INCOME STATISTICS FOR FARM HOUSEHOLDS AND ALL UK HOUSEHOLDS}

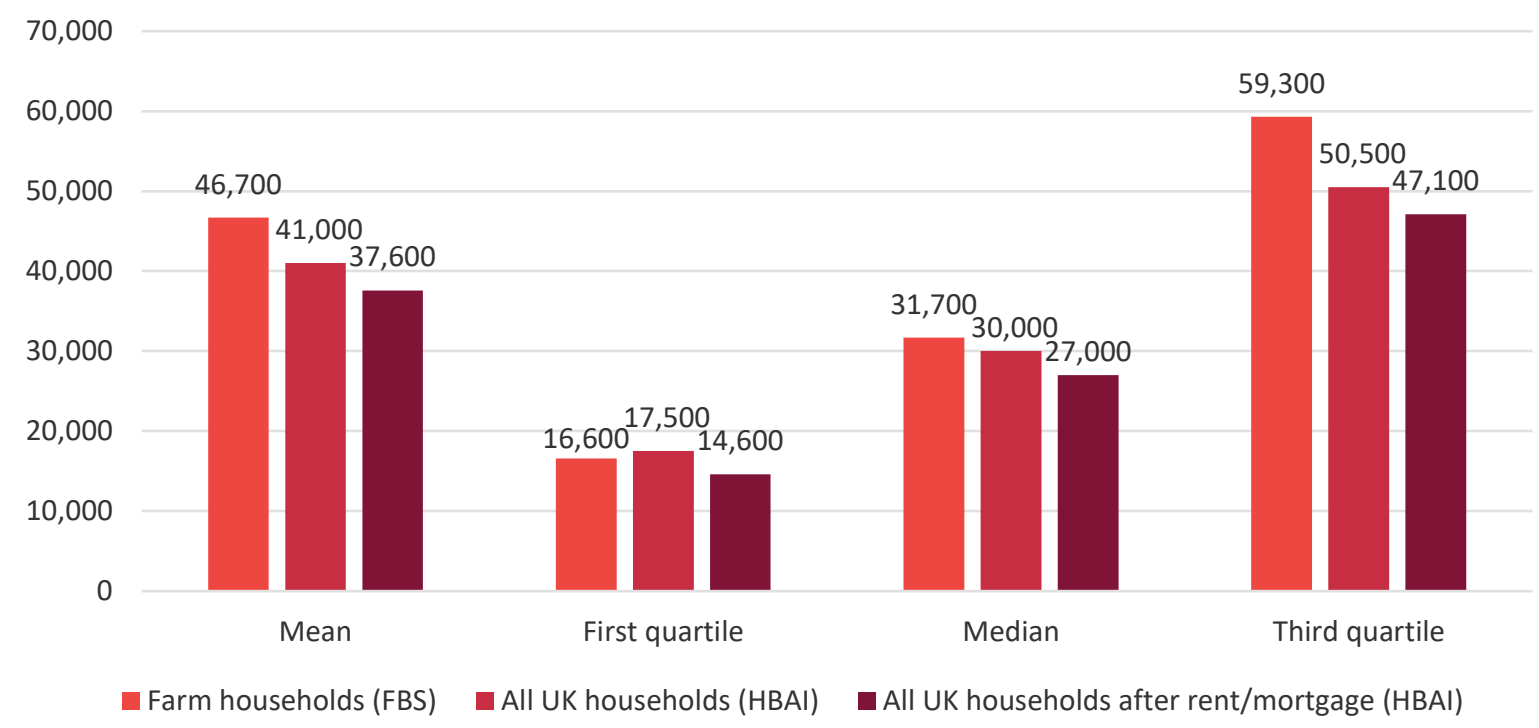

Notes: Household income is measured gross of tax payments, and includes all income received by the household of the principal farmer.

Source: Defra (2016), Farm household income and household composition - England 2014/15 (Farm Business Survey); DWP (2016) Households Below Average Income 2014/15.

The majority (67\%) of all farm businesses are comprised of a single farming household. These number 38,700 in England. The statistics which follow represent these households only. A further $29 \%$ of farming businesses are comprised of two households only, and $4 \%$ three or more households.

The gap between household income and farm net worth among single farming households is relatively large (Fig. 13), though we should keep in mind that this is effectively measured after housing costs. Around a quarter of family farms (around 9,600) have household income less than $£ 14,300$. Among these households, median net worth held in the farming business is $£ 500,000$, 
meaning most would not pay a wealth tax with an exemption threshold of $£ 500,000$ or more per individual. Families with household incomes between $£ 28,200$ and $£ 54,000$ have farms worth $£ 0.9$ million at the median. Again, if this is divided between a couple, many of these farms are unlikely to be taxed. Meanwhile, many farm households with income in excess of $£ 54,000$ are likely to be taxed as part of a wealth tax with an exemption threshold of $£ 500,000$ per individual: the average net worth of these businesses is $£ 1.4$ million

\section{FIGURE 13: MEDIAN (FARM) NET WORTH (EM) BY FARM HOUSEHOLD INCOME RANGE}



Notes: Household income is measured gross of tax payments, and includes all income received by the household of the principal farmer. Net worth includes all assets owned by the farm business, including land (where applicable), machinery etc., net of liabilities. Net worth is measured on a conservative market value basis.

Source: Defra (2016), Farm household income and household composition - England 2014/15. 


\section{Conclusion}

Though it is not possible to put an exact number on the businesses that would need to be valued under a UK wealth tax, it is not the case that all of the UK's 6 million businesses would need to be valued. A majority of these (60\%) are small businesses with no employees, and many are unlikely to be valuable enough (or have owners who are wealthy enough) to be taxed. This brings the potential number of valuations down significantly.

There are several options for valuing private businesses, and income-based valuation approaches could be a core input to the valuation of the majority of businesses, used in combination with asset-based valuations for businesses with unobservable or inconsistent profit streams. Even for high growth tech firms, which can be challenging to value both because their profit streams are rapidly changing, and because a significant proportion of their assets are intangible, there are opportunities: many of these businesses have secured private equity investment, providing an observable transaction on which a valuation could be based.

While it may be the case that some business owners would be liquidity constrained when faced with a wealth tax liability (Loutzenhiser and Mann, 2020), there is reason to think that some of these business owners could extract additional income from their business in order to pay the tax, as many companies have accumulated significant amounts of retained earnings. Moreover, it seems unlikely that multi-shareholder issues would pose a widescale constraint on accessing these funds. While solutions to the liquidity constraints highlighted in Loutzenhiser and Mann (2020) are certainly needed, it is worth noting that focusing on what business owners currently receive means that we will miss additional liquidity business owners may have access to.

Farming business in particular will be highly likely to be taxed, and in this paper we find that farms in the General Cropping and Cereal sectors are most likely to be within scope. There is some support for the concern that some farm business owners would face liquidity constraints, not because the overall return to farming is low, but because the return to farmland (as the largest farming asset) derives primarily from capital growth rather than income yields. However, though the number of farms making a loss is not insignificant, it is also true that a significant proportion of farming businesses generate more than enough income to finance a wealth tax.

A more comprehensive analysis of valuation and liquidity issues affecting private businesses would be possible with the availability of better data. Firmer conclusions on the number of businesses that would require valuation could be reached with better data on the characteristics and value of UK businesses. Regarding liquidity issues, the extent to which owners of unincorporated businesses could extract additional income remains unclear, as much of the analysis presented in Sections 4.2 and 4.3 pertains to unlisted companies. In general, research on the UK private business population would progress immeasurably if data were collected in a consistent manner across a broad range of businesses. At present, research is limited by having to piece together fragmented pieces of evidence from a wide range of sources. 


\section{References}

Advani, A., \& Summers, A. (2020). How much tax do the rich really pay? New evidence from tax microdata in the UK. CAGE Policy Briefing No.27.

BEIS. (2020). Business population estimates for the UK and regions 2020: detailed tables. Department for Business, Energy and Industrial Strategy.

BIS. (2012). Guide to the UK Business Population and Demography. Department for Business, Innovation and Skills. Retrieved from https://www.gov.uk/government/statistics/guide-tobusiness-statistics

Burges Salmon. (2016). Tax changes for individual shareholders receiving a distribution in a liquidation by way of MVL.

BVA BRDC. (2020). SME Finance Monitor: Q4 2019.

Clark, E., \& Fu, S. (2020). Valuation of agricultural property. Wealth Tax Commission Background Paper, No. 145.

Companies House. (2020, June 25). Companies register activities: 2019 to 2020. Retrieved from Gov.uk: https://www.gov.uk/government/publications/companies-register-activitiesstatistical-release-2019-to-2020/companies-register-activities-2019-to-2020\#incorporatedcompanies

Corrado, C., Hulten, C., \& Sichel, D. (2005). Measuring Capital and Technology: An Expanded Framework. In C. Corrado, J. Haltiwanger, \& D. Sichel, Measuring Capital in the New Economy (pp. 11-46). University of Chicago Press.

Daly, S., \& Loutzenhiser, G. (2020). Valuing assets and debts. Wealth Tax Commisssion Evidence Paper, 9.

Defra. (2016). Farm household income and household composition 2014/15. Department for Environment, Food \& Rural Affairs.

Defra. (2018). Moving away from Direct Payments. Department for Environment, Food and Rural Affairs.

Defra. (2020a). Agriculture in the United Kingdom 2019. Department for Environment, Food and Rural Affairs.

Defra. (2020b). Balance sheet analysis and farming performance, England 2018/2019. Department for Environment, Food \& Rural Affairs.

Defra. (2020c). Farm Accounts in England 2018/19. Department for Environment, Food \& Rural Affairs.

Department for Work and Pensions. (2020). Households Below Average Income, 1994/952018/19 [data collection]. 12th Edition. UK Data Service. SN: 5828. doi:http://doi.org/10.5255/UKDA-SN-5828-12

Global Witness. (2018). The companies we keep: what the UK's open data register actually tells us about company ownership. 
Goodridge, P., Haskel, J., \& Wallis, G. (2014). Estimating UK investment in intangible assets and Intellectual Property Rights. Intellectual Property Office.

Keilloh, G., Chhatralia, K., \& Johnson, C. (2015). Profit distribution and investment patterns of unlisted companies. HM Revenue and Customs Research Report No. 390.

Loutzenhiser, G., \& Mann, E. (2020). Liquidity issues: solutions for the asset-rich cash poor. Wealth Tax Commission Evidence Paper, 10.

ONS. (2019a). Business demography, UK: 2018. Office for National Statistics. Retrieved from https://www.ons.gov.uk/businessindustryandtrade/business/activitysizeandlocation/bulletins /businessdemography/2018

ONS. (2019b). Developing experimental estimates of investment in intangible assets in the UK: 2016. Retrieved from www.ons.gov.uk: https://www.ons.gov.uk/economy/economicoutputandproductivity/productivitymeasures/art icles/experimentalestimatesofinvestmentinintangibleassetsintheuk2015/2016

OTS. (2014). Review of partnerships: interim report. Office of Tax Simplification.

Ryan, D. (2020). Valuation of businesses and intellectual property assets. Wealth Tax Commission Background Paper, No. 144.

Savills. (2015). Market Survey: UK Agricultural Land.

Savills. (2019). The Farmland Market. Spotlight Savills Research.

Savills. (2020). The Farmland Market. Spotlight Savills Research: UK Rural.

The Sunday Times. (2020). Tech Track 100 Research Report 2020: Britain's fastest growing private technology companies.

The Sunday Times. (2020). Top Track 100 Research Report 2020: Britain's 100 biggest private companies.

The Sunday Times. (2020). Top Track 250 Research Report 2020: Britain's leading mid-market private companies. 


\section{Appendix A: Data sources}

This appendix provides additional information on each data source referred to in the main body of the paper, including which businesses are represented in the statistics and the methodology used to collect the data.

\section{Companies House Register}

Companies House publishes information on the population of companies and corporate bodies incorporated in the United Kingdom. A company is a specific legal form of business which is incorporated/registered at Companies House. The register includes inactive companies. Dissolved companies are excluded.

\section{Keilloh et al. (2015) "Profit Distribution and Investment Patterns of Unlisted Companies"}

HMRC published evidence on profit distribution and investment patterns among active unlisted companies based on a survey conducted by Ipsos Mori. Unincorporated businesses are not represented. The survey was conducted by telephone and included 1,501 randomly selected unlisted companies. The data are not completely representative of the population of UK unlisted companies, as medium and large companies were deliberately over-represented. Moreover, response rates were low at just 38\% due to difficulties in contacting companies and a high nonresponse rate among those successfully contacted.

\section{BVA BRDC "SME Finance Monitor"}

The SME Finance Monitor surveys 4,500 businesses each quarter, focusing mainly on borrowing events and intentions. Data are collected through interviews. To be eligible for the survey, a business must not be majority-owned by another company; must not be run as a social enterprise or non-profit organisation; and must have a turnover of less than $£ 25$ million. The sample covers both incorporated and unincorporated (sole proprietorship) businesses.

\section{BEIS Business Population Estimates}

Business Population Estimates provide a comprehensive estimate of the total UK business population. The statistics include incorporated business (both private and publicly listed), and unincorporated businesses (sole proprietorships and ordinary partnerships), whether registered for VAT or PAYE or not. The estimates are based on the ONS Inter-departmental Business Register (IDBR), which only includes 'active' businesses - those with VAT and/or PAYE activity during the reference year. The IDBR excludes companies set up for purposes not directly related to economic activity, such as the protection of names, or clubs and societies. Data from Companies House and other government departments are combined, and 'enterprises' are created, which may combine multiple company registrations into a single business. The IDBR also excludes companies that are registered in the UK but are only active overseas.

\section{ONS Business Demography Statistics}

Business Demography Statistics include information on births and deaths among the UK population of businesses that are 'active' - with VAT and/or PAYE activity at any point in time 
within the year. The statistics are based on the ONS Inter-departmental Business Register (IDBR). However, they only represent businesses registered for VAT and/or PAYE, and so do not represent the unregistered population. The data cover both incorporated and unincorporated (sole proprietorship) businesses. See above for additional information on the IDBR.

\section{The Sunday Times Top Track 100}

The Top Track 100 ranks Britain's biggest private companies by sales. Companies must be unquoted, not subsidiaries, and registered in the UK to be eligible for the list. To construct the list, companies are identified by researching accounts filed at Companies House and financial data provide by BVD's FAME database. The data collectors also review more up-to-date accounts where companies are willing and able to provide them. The list excludes companies majority owned by, or joint ventures between, quoted companies. It also excludes companies with fewer than 100 staff. Sales are measured as turnover, as reported in companies' latest accounts. Companies do not have to be in profit to be included in the list. The researchers recognise that there may be omissions from the list where companies have incomplete data, and welcome nominations for future league tables.

\section{The Sunday Times Top Track 250}

The Top Track 250 ranks Britain's leading mid-market private companies according to sales. The list consists of the 250 next-biggest private companies beyond the 100 biggest companies included in the Top Track 100 (see above). Eligibility criteria differs somewhat to those for the Top Track 100. To be eligible for the list, companies must have operating profit margins in excess of $2 \%$ (note that the Top Track 100 does not require companies to be in profit). Sales must have grown by at least $5 \%$ in the latest year for those with highest sales, $10 \%$ for those with lower sales, or profit growth must have been $5 \%$ or more. Sales must be no more than $£ 750$ million. Sales are taken from the latest available accounts Companies must be UK registered and be independent, unquoted and ultimate holding companies. The list is constructed using data from BVD's FAME database, Companies House and Experian's MarketIQ. Some companies did nominate themselves for the list, and researchers acknowledge that the list may be incomplete.

\section{The Sunday Times Tech Track 100}

The Tech Track 100 ranks private technology, media and telecoms companies based on their growth in sales over the last 3 years of available data. The Sunday Times use the London Stock Exchange definition of a tech firm as "one that shows a 'commitment to innovation, research and product development' and operates in sectors including software, internet, telecoms and biotech". Companies are ranked by growth in sales over their last three years of available accounts, and are selected from a database of around 2 million private companies. Telephone interviews and company visits are conducted as part of the list compilation process. To be eligible for the list, companies must be an independent technology, telecoms or media company; registered in the UK; unquoted and not a subsidiary; have annual sales in excess of $£ 250,000$ in the base year; have annual sales of at least $£ 5$ million in the final year; have year-on-year sales growth from penultimate to latest year; have at least 25 trading weeks in the base and final year; not be a payday lender or pure computer seller; for IT consultancies and service companies, a significant proportion of sales must come from proprietary technologies. 


\section{Farm Business Survey}

The Farm Business Survey collects information on the financial, physical and environmental performance of farm businesses in England. The survey is restricted to farm businesses which have at least 25,000 Euros of annual standardised output recorded in the annual June Survey of Agriculture and Horticulture. All types of farm are included. It is a panel survey with a sample size of around 1800 farms. Data are collected via face-to-face and telephone interviews. Nonresponse rates are high, at around $90 \%$ of those approached who are in scope. Calibration weighting is applied to minimise bias arising from non-response. Results from the survey are published in various statistical releases. The two used in this paper are described in more detail below.

\section{Balance sheet analysis and farming performance, England 2018/19}

The balance sheet analysis is based on a subset of FBS respondents who have complete returns on their assets and liabilities. In 2017/18, this included 1768 farms. The data are weighted to represent all farms which have a standard output of at least 25,000 Euros.

\section{Farm household income and household composition 2014/15}

As part of the FBS, information is collected on the household income of the principal farmer from each farm business. No information is collected from other farmers or partners, who are present in just under a third of all farming businesses. This information is only collected from a subsample of 1,000 respondent businesses, whose responses are weighted to reflect the total population of farm businesses. Figure 12 in this paper (Section 5.2), which shows farm median net worth by household income range, is based only on the subset of farm businesses which are controlled by a single family, which make up $67 \%$ if the population. This dataset was last published in 2014/15. 


\section{Appendix B: Farm business profits by region}

This appendix shows how farm business profits vary by farm region. As for farm types (Section 5.2), we see that farms in regions with a higher share of high net worth farming businesses earn more profit, on average (Fig. 12). The most valuable farming businesses on average, located in the East of England, earn average FBI of $£ 78,200$.

\section{FIGURE 14: AVERAGE PROFIT (FBI) AND AVERAGE NET WORTH, BY REGION}

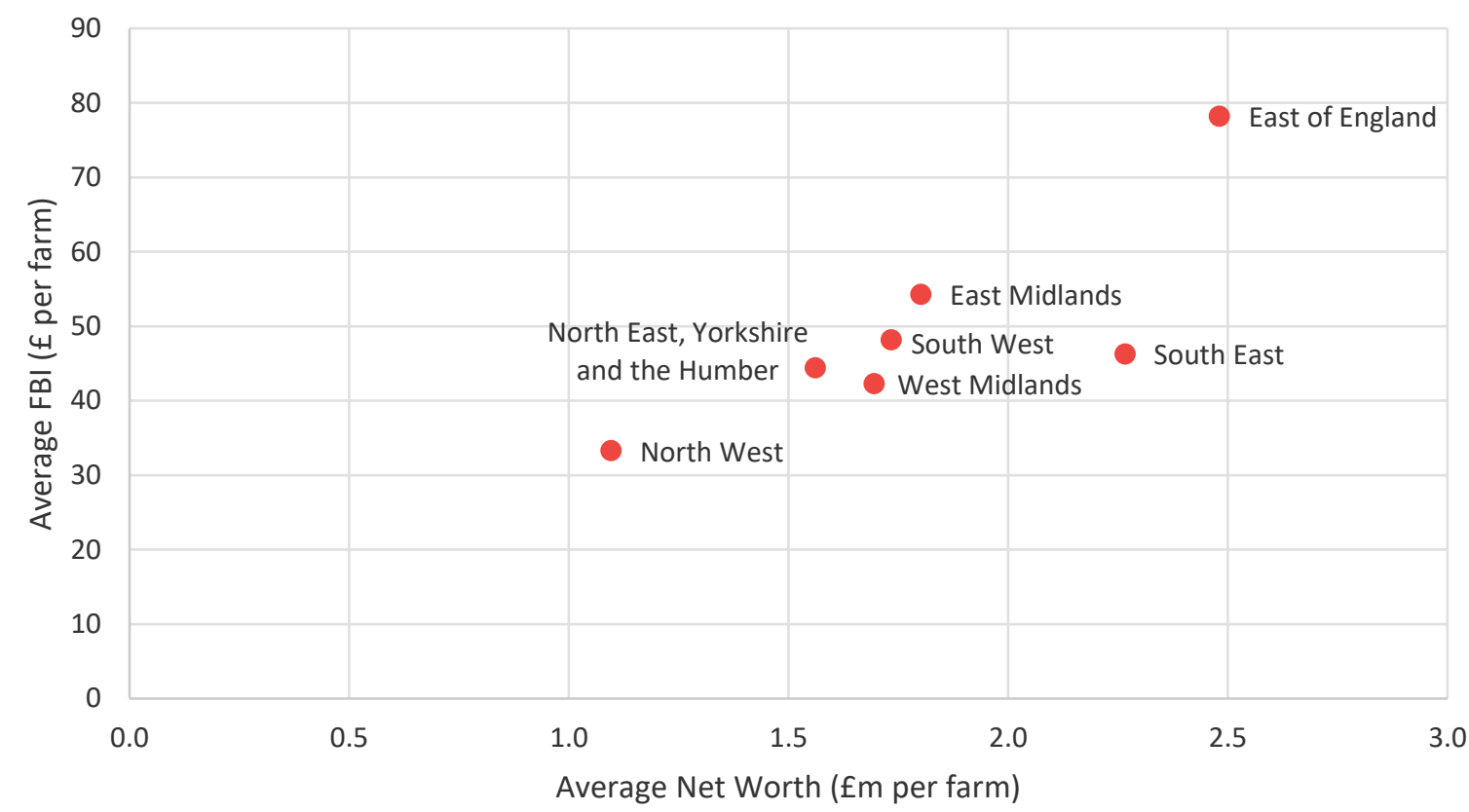

Notes: Farm Business Income (FBI) includes income from agricultural activities and diversified activities such as recreation, tourism, solar energy, retail, and subsidy payments, as long as the business also produces agricultural output. It excludes income going to landlords. Net worth includes all assets owned by the farm business, including land (where applicable), machinery etc., net of liabilities. Net worth is measured on a conservative market value basis. See Section 5.1 for details.

Source: Defra (2020b) Balance sheet analysis and farming performance, England 2018/19 (Farm Business Survey); Defra (2020c), Farm Accounts in England 2018/19 (Farm Business Survey). 